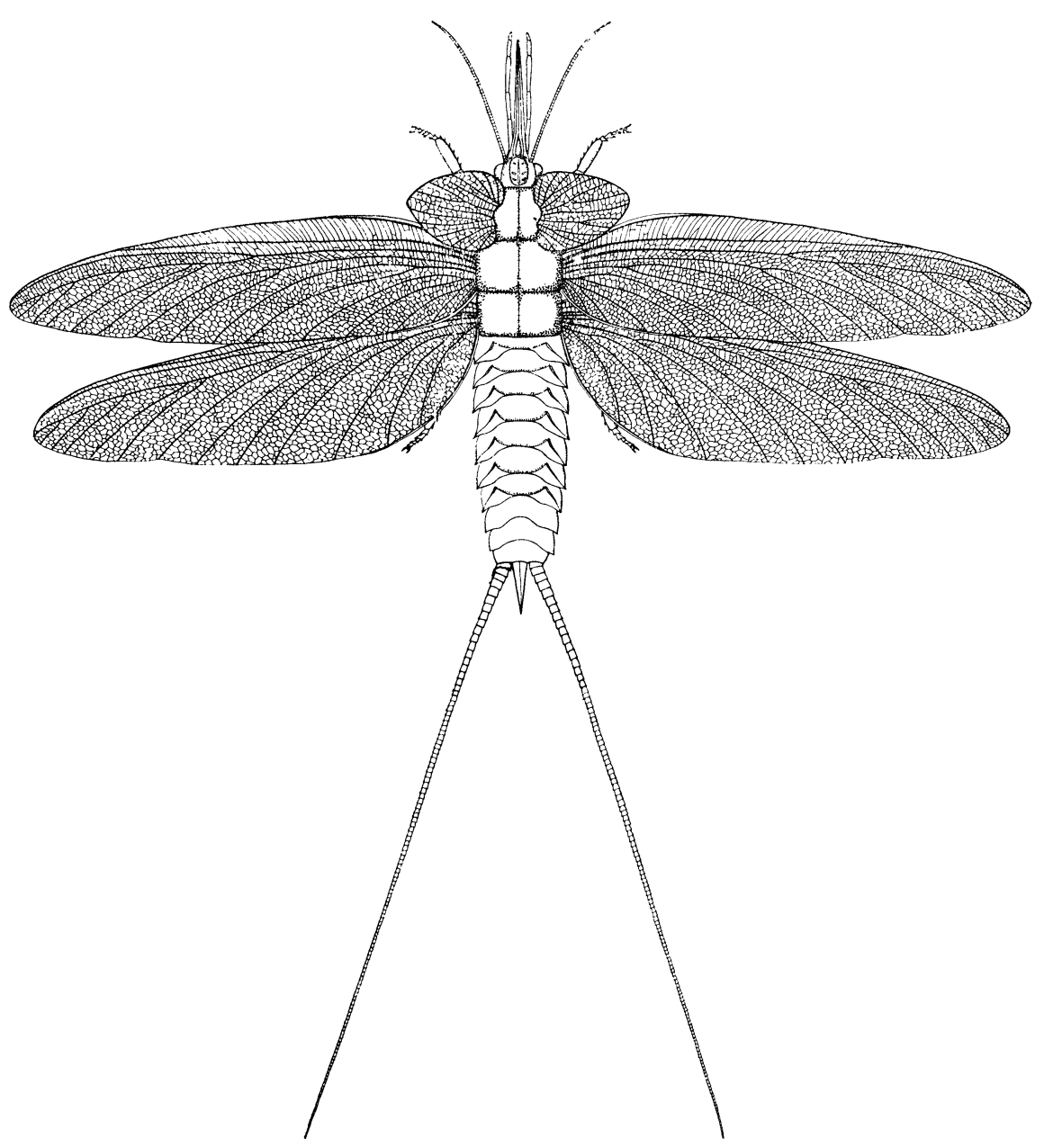

Figure 50. Reconstruction of Stenodictya based on specimens in the Institut de Paléontologie, Paris. For explanation, see text. 


\title{
PSYCHE
}

Vol. 77 March, I970 No. I

\section{REVISIONAL STUDY OF \\ THE ORDER PALAEODICTYOPTERA IN \\ THE UPPER CARBONIFEROUS SHALES OF COMMENTRY, FRANCE. PART III ${ }^{1}$}

\author{
By Jarmila Kukalova ${ }^{2}$ \\ Charles University, Prague
}

The first two parts of these studies have dealt with eight families of the Palaeodictyoptera in the Commentry collection at the Institut de Paléontologie in Paris. The introductory discussion in Part I summarized the background of this investigation and the extent of the collection studied. The present part deals with the remaining family, the Dictyoneuridae, which is well represented in the Commentry shales. Some of the fossils of this group provide us with structural details that are otherwise unknown in the Palaeodictyoptera. In the concluding paragraphs of this paper I have summarized what is known of the wing and body structures of this extinct order of insects.

\section{Family Dictyoneuridae Handlirsch ${ }^{3}$}

Stenodictyopterida Brongniart, 1885: 60; Brongniart, 1893: 380 .

Stenodictyopteridae Pruvost, 1919: 98; Laurentiaux, 1953: 419.

Dictyoneuridae Handlirsch, 1906: 63; Handlirsch, 1911: 297; Lameere, 1917: 102; Handlirsch, 1919: 3.

Stenodictyidae Laurentiaux, 1952: 234.

\footnotetext{
${ }^{1}$ Published with the aid of a grant from the Colles Fund of the Museum of Comparative Zoology at Harvard College and a Grant-in-Aid of Research from the Society of the Sigma Xi. This study has also been supported in part by grants numbered GB2038 and GB7038 (F. M. Carpenter, Principal Investigator) from the National Science Foundation. Part I, dealing with the family Spilapteridae, was published in Psyche, Vol. 76, pp. 163-215; part II, dealing with seven additional families, was published in Psyche, Vol. 76, pp. 439-486.

${ }^{2}$ Alexander Agassiz Lecturer in Zoology, Harvard University, 1969.

${ }^{3}$ As noted by Handlirsch (1906) the name Stenodictyopteridae, which was not based on a generic name, is invalid. The name Stenodictyidae, used by Laurentiaux and based on Stenodictya, presumably in an attempt to retain a name similar to the one used by Brongniart, is, of course, a synonym of Dictyoneuridae, which was correctly formed by Handlirsch in 1906.
} 
Type Genus: Dictyoneura Goldenberg, 1854 .

Brongniart originally conceived of this family as characterized by the presence of a dense archedictyon and a specialized venation in which there were few branches. Marked attention was given to this family in later years and it played an important role in hypotheses on insect phylogeny. Brongniart's original and apparently correct conclusion on the specialized nature of the venation in this family was rejected or modified by subseqent investigators. Handlirsch, who considered the morphology of Stenodictya as supporting his theory of trilobite ancestry of insects [by having the prothoracic lobes and abdominal expansions derived from the trilobite cephalon and pleura (1908, p. 1304)], believed the Dictyoneuridae to be the most primitive of all Pterygota. He also thought the order Palaeodictyoptera was ancestral to all other insect orders. This latter view was rejected by Martynov (1925, 1938), who did, however, follow Handlirsch (1938, p. 19, 21) in his conviction that the Dictyoneuridae were the most primitive of the Palaeodictyoptera. Martynov based his conclusions on the presence of four features in the family: a uniform archedictyon, well developed prothoracic lobes, paranotal expansions along the abdomen, and a primitive venational pattern, the veins having few branches.

In the light of information acquired in recent years, the archedictyon seems to be only one of these traits that can be considered as primitive. In the geological record of insects, the archedictyon appears repeatedly in the more ancient forms of primitive groups, becoming irregular or reduced to cross veins in more advanced forms (e.g., Paleozoic Blattodea, Protorthoptera, etc.). On the other hand, the prothoracic lobes of Stenodictya and of other Dictyoneuridae, as far as known, do not differ from those of other Palaeodictyoptera and cannot be considered as being more primitive. Previous interpretations of the so-called expansions of the abdomen in Stenodictya seem to be very questionable, after careful study of the type specimens concerned. Incorrectly figured by Brongniart, who considered them to be homologous to the tracheal gills of mayfly nymphs, the expansions seemed to Handlirsch and Martynov as evidence for their respective hypotheses on insect evolution. Handlirsch assumed that the paranotal expansions of the abdomen of insects were derived from the pleura of trilobites because of the presence of an "oblique furrow." In his hypothesis on the origin of the Pterygota, Martynov assumed that wings of insects arose from the paranotal expansions which developed in hypothetical ancestral 
forms on both the thorax and the abdomen, as they are still partially present in some Recent Thysanura (Lepismatidae). He considered the lateral abdominal expansions of Stenodictya to represent a very primitive stage of this development at a time when they were not yet completely reduced.

My examination of the Commentry dictyoneurids throws an entirely different light on the problem. The abdominal tergites of Stenodictya are heavily sclerotized with pointed and even prolonged posterolateral angles directed obliquely backwards. They are provided with oblique ridges, which, of course, have nothing to do with the "oblique furrow" of trilobite pleura, but are secondary structures, undoubtedly serving to strengthen the lateral parts of tergites. The longitudinal suture, separating the lateral parts of tergites in some other families of Palaeodictyoptera, is completely missing. Since the abdomen of Stenodictya was relatively broad, decomposition processes had a marked effect on the relationship of abdominal segments, as preserved. They were widely separated from each other so that much of the intersegmental membrane between the tergites is visible in most specimens. The prolonged posterolateral angles of tergites consequently overlap the following segments much less and they protrude much more towards the sides. Simply by cutting out single segments of an exact figure and arranging them back to normal position, the abdomen becomes shorter, with the tergites slightly protruding. The abdomen, so reconstructed, is very suggestive of that of many Neoptera (e.g., roaches) and undoubtedly represents a derived, specialized state of development. Other body parts of Stenodictya were heavily sclerotized as well, with deep, dense pits, exceptional for the Palaeodictyoptera. This strengthened cuticle probably provided protection against injury. Much more primitive, in my opinion, is the abdomen of some Palaeodictyoptera that have lateral lamellae present, i.e., with lateral parts of tergites separated by a longitudinal suture extending from the notum. These structures are probably homologous with lateral lamellae of some living mayfly nymphs but their function is not yet explained.

Martynov considered the venation of the Dictyoneuridae as the most primitive in the Palaeodictyoptera because of the presence of only a few branches (Comstock and Needham, i 898-99). The geological record, on the other hand, supports Redtenbacher's ( I 886) concept of the richer wing venation being present in the more ancient groups. This idea was followed and developed further by Lameere 
(1922). For that reason I consider the venation of the Fouqueidae, and to a lesser extent that of the Spilapteridae, as more primitive and much closer to the supposedly ancestral type than that of Dictyoneuridae. Especially primitive, perhaps, are those genera with richly branched, convex and concave parts of $\mathrm{M}$ and $\mathrm{Cu}$.

The venation of the Dictyoneuridae is an extremely simplified one for the Palaeodictyoptera and provides little basis for differentiation of taxa. It is therefore necessary to study the specimens in as much detail as possible in order to obtain full information. From my study of the Commentry material I am of the opinion that differences in cell shape of the archedictyon, the detailed outline of the posterior margin on the wings and distribution of cross veins and of the archedictyon may be useful for taxonomy. Nevertheless, the classification of isolated wings at both specific and generic levels is less satisfactory than in other families of the order.

In the Dictyoneuridae, the postcostal area is differently developed from that of all other families of Palaeodictyoptera. Arising from the very base of $\mathrm{C}$, a single postcostal vein follows along the subcosta and terminates shortly on this vein. Commonly in the Palaeodictyoptera this subcostal vein is directed obliquely towards the costa, delimiting a triangular area and giving rise to several fine twigs. In the Dictyoneuridae also the precostal strip is very pronounced and broad, extending over the first third of the wing. Examining the other more specialized families, such as Eugereonidae, Calvertiellidae and Archaemegaptilidae, we note that the postcostal vein is completely reduced; on the other hand the precostal membranous strip is enlarged to form a true precostal area. The Dictyoneuridae apparently show the way in which the postcostal area became reduced in favor of the precostal area in the more advanced and specialized families. There is no doubt that the precostal area is a "younger" feature than the postcostal area, which developed by radial evolution in some groups only.

Thanks to Handlirsch's reconstruction, published in numerous textbooks of entomology and palaeontology, Stenodictya lobata is undoubtedly the most famous fossil insect known. Unfortunately, as this revisional study shows, no one feature given in Handlirsch's reconstruction is correct. In contrast to what he figures, the mouthparts of Stenodictya are actually modified for sucking, the head is provided with a large clypeal region, the prothoracic lobes have a venation and a cross venation, the wings are more slender distally than represented, Rs has more numerous branches, the arche- 
dictyon is replaced by cross veins in the subcostal and sc-r areas, the tarsal segments are five in number, the abdomen shorter and narrower than represented, the lateral lamellae are not present (the posterolateral angles of tergites projecting only slightly), and the cerci are robust and long. Finally, Handlirsch's figure includes a combination of male and female features. His reconstruction of the prothoracic lobes, wings and part of the abdomen were based on Brongniart's specimen 22-I, which is a female, as shown by the presence of an ovipositor (see Figure 50). On the other hand, the end of the abdomen of Handlirsch's reconstruction was based upon Brongniart's specimen 22-2, which turns out to be a male and which probably represents a distinct species. The male claspers, incidentally, were misinterpreted by Handlirsch (Lameere, I9I7, p. 158$)$.

Following the significant discovery by Laurentiaux (1952) of the presence of the sucking beak in a previously unstudied specimen of Stenodictya (collection of the Institut, Paris), doubts about the presence of a beak in all Palaeodictyoptera have disappeared. On the basis of the photograph in Laurentiaux's paper, Sharov (I966, p. II 8) gave a new reconstruction of Stenodictya. However, this reconstruction is also incorrect, mainly because the specimen itself was preserved so as to show a ventral view, although this was not apparent from the photograph. As a result, Sharov erroneously interpreted several features as dorsal in position. For example, the prothoracic lobes, appearing from underneath the body, were interpreted as a prothoracic shield; and vague outlines of a structure shown on the photograph only as the result of shading (but completely invisible in the specimen itself) is represented in the restoration as a separate small segment at the base of the beak in the place where, in the dorsal surface of the Palaeodictyoptera, there is the triangular, elongate labrum. Furthermore, the beak as represented in. Sharov's reconstruction, should be longer than drawn, with long palpi present; the wings should have cross veins in the subcostal and the sc-r areas, the legs should have five tarsal segments; the cerci should be somewhat longer and the posterolateral angles of the tergites less projecting.

In the accompanying illustration (Figure 50) I am including a reconstruction of Stenodictya which, it should be noted, is a composite of structures present in several species of the genus, as follows: $S$. lobata Brongniart, specimen 22-I, for head, eyes, clypeus, prothoracic lobes, venation of fore and hind wings (in part), thorax, 
abdomen, ovipositor, cerci; S. pygmaea Meunier for the shape of the prothoracic lobes; $S$. oustaleti Brongniart, specimen 22-3, and $S$. agnita (Meunier) for the five-segmented tarsi and legs; and $S$. laurentiauxi, n.sp., for the beak. It should also be pointed out that since the maxillary palpi are incompletely preserved in any specimen of Stenodictya, they have been represented in the restoration to the length of those in Eugereon boeckingi Dohrn; the labrum, which is indistinct in specimens of Stenodictya, is drawn as it is in various species of Palaeodictyoptera belonging to other genera; and the length of the ovipositor, also incomplete in specimens of Stenodictya, is drawn to its length in Homaloneura ornata Brongniart.

A dense archedictyon, more or less approaching that of the Dictyoneuridae and related families, occasionally occurs within the homoiopterid and spilapterid groups of families. In the Homoiopteridae it is very dense, for example in Boltopruvostia nigra (Kukalová, 1958), and it is well developed in Homoioptera woodwardi. In the Spilapteridae, the archedictyon is presumably completely reduced in all genera and the anastomoses between the cross veins are only rarely present, but the cross veins themselves are exceptionally dense. Nevertheless, in the closely related family Eubleptidae, there is a dense archedictyon between the cross veins. A special case of modified archedictyon occurs in the Fouqueidae, particularly in the genus Fouquea. The coarse, extremely dense cross venation in that genus recalls very much the process which has taken place in some roaches, in which the dense reticulation in the more primitive Carboniferous forms became restricted into markedly dense patterns in Permian forms. Nevertheless, among all Palaeodictyoptera, the archedictyon of the Dictyoneuridae is certainly the most even and tends least to form cross veins. Its presence, together with specialized morphological features, is not surprising, this phenomenon being known as mosaic evolution.

Of the genera included in the Dictyoneuridae by Laurentiaux (1953), Athymodictya Handlirsch is to be referred to the Eubleptidae, Dictyoneurella Laurentiaux to Archaemegaptilidae, Mecynoptera Handlirsch perhaps to Archaemegaptilidae and Boltopruvostia Pruvost to the Homoiopteridae.

The following are the basic characteristics of the Dictyoneuridae: Fore and hind wings very similar. Main veins without coalescence. Sc ending on costal margin beyond midwing; $\mathrm{R}_{\mathrm{I}}$ extending nearly to apex; Rs with several branches; MA unbranched, usually strongly 
curved; MP simple or branched; $\mathrm{CuA}$ unbranched; $\mathrm{CuP}$ simple or having several branches. Archedictyon well developed over most of the wings and usually dense.

Body structures: head with small projecting eyes and large clypeus. Antennae multisegmented, long. Prothoracic lobes large, with about eight radiating veins, often branched, and numerous, anastomosing cross veins; thoracic segments uniformly long, though the prothorax may be somewhat shorter than the others. Legs short, robust, tarsus 5-segmented, with claws and arolium. Abdomen relatively broad and short. Cerci in females long, multisegmented. Ovipositor in female curved, stout, reaching beyond the end of the body. Males with claspers arising laterally from the subgenital plate, composed of homonomous, carinated plates, directed obliquely and touching distally. Body and wings completely and densely covered by deep pits. All body parts heavily sclerotized.

The family Dictyoneuridae is related to the Eugereonidae, Archaemegaptilidae and Protagrionidae and is more distantly related to the Megaptilidae and Calvertiellidae.

The genera included in the Commentry shales: Stenodictya Brongniart, Microdictya Brongniart. The following genera, also in the family Dictyoneuridae, are from the Stephanian of Germany: 1)ictyoneura Goldenberg. Stilbocrocis Handlirsch, Cleffia Guthörl, Rotundopteris Guthörl, Polioptenus Scudder, Dictyoneurula Handlirsch, Goldenbergia Scudder, Sagenoptera Handlirsch, Kallenbergia Guthörl and possibly Gegenemene Handlirsch.

\section{Genus Stenodictya Brongniart}

Scudderia Brongniart, 1885: 61; Brongniart, 1885: 277 (nomen nudum).

Scudderia Brongniart, 1890: 5 (nec Scudderia Grote, 1873).

Stenodictya Brongniart, 1893:383 ; Handlirsch, 1906:63; Handlirsch, 1919:3 ; Pruvost, 1919: 308; Crampton, 1919: 54; Lameere, 1917: 157; Iaurentiaux, 1953: 419; Sharov, 1966: 118.

Type species: Scudderia lobata Brongniart, I890, SD Brongniart, I 893.

'This genus was based originally on two species, lobata and spinosa, which Brongniart subsequently ( I893) and incorrectly merged under one species, lobata.

In the Commentry collections in the Institut in Paris there are 22 specimens not figured or described by previous workers. These are mostly isolated wings and fragments of wings. Presumably, the flatness of the dictyoneurid wings and the indistinct venation prevented Brongniart and Meunier from making satisfactory observations on these specimens. By using glycerin, however, I was able 
to work out the venation satisfactorily and to add descriptions of thesc specimens to the account included here.

Since the venation of the Dictyoneuridae is very simplified, as well as homogenous but individually variable, it does not offer much basis for taxonomy. The relative positions of the Rs origin and the $M$ division into MA and MP, used as specific and even generic characters by many authors, may vary even within one individual specimen's fore and hind wings (see for example Stenodictya laurentiauxi sp. nov.). Also, the number of branches can only be used to a limited extent, as additional twigs are frequently formed by the archedictyon, elements of which may or may not reach the posterior margin. Having rich material for comparison at my disposal, I find that the general outline of the wings, especially the degree of undulation of the posterior margin and the detailed structure of the archedictyon (shape and size of cells, areas occupied by cross veins, presence of twigs) are the same in fore and hind wings and are therefore additional and useful taxonomic characters.

In view of the situation noted above, I believe it is not advisable to form new genera in this family unless they are completely obvious and necessary, since such taxa just cannot be satisfactorily substantiated. I have not been able to study Dictyoneuridae in deposits other than that of Commentry but it seems very probable that the total number of genera will diminish after revisional studies. ${ }^{4}$

The wings of the Dictyoneuridae are about equal in length or the hind pair may be a little shorter; they are similar in venation and in the undulation of the posterior margin. Fore wing with the anterior margin strongly curved near the base. Precostal strip pronounced; postcostal veins simple, arising from the very base of $\mathrm{C}$, ending on Sc or forming a fork towards $\mathrm{C}$ and Sc. Sc terminating beyond midwing. Rs pectinate, originating at about mid-wing; MA, MP, $\mathrm{CuA}, \mathrm{CuP}$ usually simple and parallel, sometimes with additional twigs formed by the archedictyon. Anal area relatively broad, with about five anal veins, sometimes forked. Archedictyon irregular, occasionally producing twigs. In the costal, sc-r and proximal part of $\mathrm{r}-\mathrm{m}$ areas there are dense, regular cross veins,

\footnotetext{
${ }^{4}$ In the collections of the Institut, I was not able to find the type specimen of $S$. vasseuri Meunier, 1914. Since the specimen was not present in the collection in 1938 (pers. comm., F. M. Carpenter) and since no photograph of it exists, I have not included this species in my present account. $S$. minima Brongniart, 1893, is based on a very fragmentary specimen and since it shows no other characteristic than the small size, I am referring this species to Dictyoneuridae inc. gen.
} 


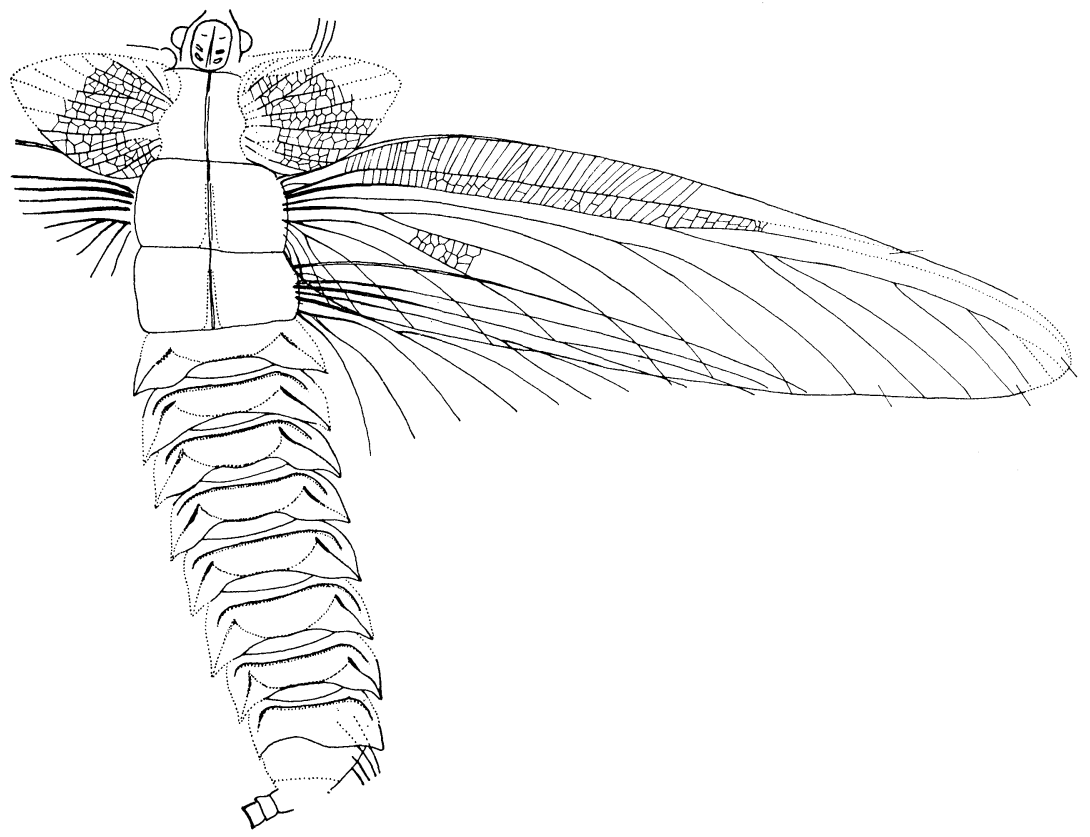

Figure 51. Stenodictya lobata (Brongniart); specimen 22-1. Holotype.

connected by anastomoses. Hind wing slightly broader, broadest shortly beyond the first quarter of wing length.

Body structures: Head small, narrower than prothorax. Eyes projecting, clypeus large. Antennae composed of narrow and long segments. Beak long, with long palpi. Prothoracic lobes large, cordate, with fan-like venation and irregular, anastomosing cross venation. Thoracic segments either equal in length or the prothorax shortest. Legs short, tibiae only slightly prolonged, sometimes provided with spines. Tarsi with long claws. Abdomen slightly longer than half the wings. Posterior margin of terga convexly curved in the central part. Posterolateral angles pointed, more or less produced. Lateral parts of terga with oblique ridges. Females with a stout, curved ovipositor and robust cerci. Males with claspers, arising posterolaterally from beneath the 9th tergite and composed of about 12 small segments of equal size, each with a short median carina.

Stenodictya differs from Dictyoneurula Handlirsch by the short Sc and simple MP. From another related genus, Microdictya 
Brongniart, it differs in having its wings broadest just beyond the base, narrower in the apical third, and by having the costal area broader, $\mathrm{C}, \mathrm{Sc}$ and $\mathrm{R}$ more curved towards the base, $\mathrm{MP}$ and $\mathrm{CuP}$ usually simple, the anal area larger, the hind wing broader and of triangular shape. From all other genera it differs in its simplified venation with unbranched $\mathrm{MP}$ and $\mathrm{CuP}$.

Species included in Commentry shales: Stenodictya lobata (Brongniart, I885); S. spinosa (Brongniart, I885); S. agnita (Meunier, 1908); S. pygmaea (Meunier, I9II) ; S. grandissima (Meunier, I9II) ; S. oustaleti (Brongniart, I893); S. arnaudi (Brongniart, I893); S. klebsi (Meunier, I908); S. laurentiauxi spec. nov.; $S$. parisiana spec. nov.

\section{Stenodictya lobata (Brongniart)}

Figures 50, 51, 52

Scudderia lobata Brongniart, 1890: pl. II, fig. 2, 3.

Stenodictya lobata Brongniart, 1893: 386, pl. 22, fig. 1; Handlirsch, 1906: 64, pl. 8, fig. 20; Handlirsch, 1911: 181, pl. 6, fig. 1 (reconstruction); Handlirsch, 1913: 513 (reconstruction); Handlirsch, 1921: 129, fig. 54 (reconstruction); Handlirsch, 1919: 3; Pruvost, 1919: 98, fig. 24; Laurentiaux, 1952: 237; Sharov, 1966: 118, fig. 52 (reconstruction).

The type specimen of this species was first figured by Brongniart in 1890 (pl. 2, fig. 2, 3) as Scudderia lobata; in 1893 it was illustrated with the name Stenodictya lobata (22-I). The specimen which Brongniart figured in his latter paper (pl. 22-2) as lobata was the one on which he previously ( I890) based spinosa. As stated in the footnote on page 386 of the I 893 work, he considered spinosa to be a synonym of lobata. However, I believe that Brongniart was in error in this conclusion and I am convinced that spinosa is a distinct species. In all figures, Brongniart showed lobata (specimen 22-I) as having the incompletely preserved claspers similar to those of spinosa (specimen 22-2). This is not correct, however, the end of the abdomen on specimen 22-I being distorted and showing on the left side bases of the cerci and on the right side the base of the ovipositor.

Some confusion has existed in the literature about the lateral portions of the tergites. Lameere (I9I7, p. I58) correctly noted that the lateral parts of the tergites have the same surface texture and sclerotization as the median part of the tergites and that they are not separated by any suture from the rest of the tergites. The transverse ridge, running near and parallel to the anterior margin of the abdominal segments, Lameere considered to be a suture 

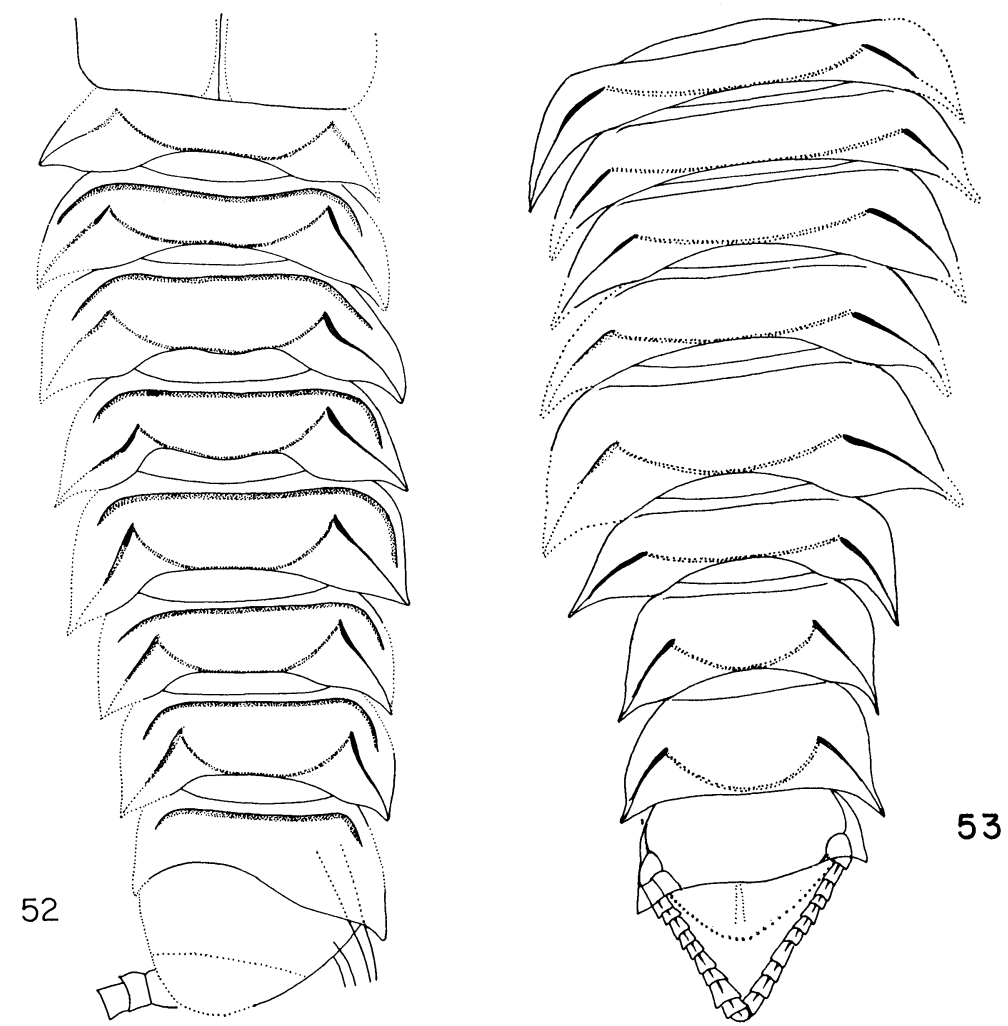

Figure 52. Stenodictya lobata (Brongniart); specimen 22-1; detail of abdomen.

Figure 53. Stenodictya spinosa (Brongniart); specimen 22-2; detail of abdomen. 
dividing the tergites. The oblique ridge which extends out from the posterolateral angles of the segment ends freely on the tergite surface and is not connected with the transverse ridge. All structures mentioned in all probability served to strengthen the abdominal wall.

Fore wing: length $66 \mathrm{~mm}$, width $\mathrm{I} 7.5 \mathrm{~mm}$. Anterior margin convex, posterior margin with a convex curvature at the end of MA; apical third of wing very narrow; subcostal area broad, but narrowing a short distance beyond the base of the wing. Rs with 5 simple branches. Anal area with 6 veins, mostly unbranched. Cross veins in the subcostal area and the sc- $r$ area dense, regular, with but few anastomoses.

Body structures: Head $1.5 \mathrm{~mm}$ long; $7 \mathrm{~mm}$ broad. Clypeus very large, quadrangular in form and having a median ridge and three pairs of transverse ridges, the anterior pair being weakly indicated. Prothoracic lobes reaching about $2 / 3$ the width of the fore wing, with 7 branched veins. Thoracic segments about equal in length and each with a median furrow. Length of mesothorax, $7.8 \mathrm{~mm}$, of metathorax $7.2 \mathrm{~mm}$. Prothorax narrower than mesothorax. Abdomen slightly broader than thorax, about $39 \mathrm{~mm}$ long. Lateral parts of abdominal segments laterally dilated; posterolateral angles pointed, projecting somewhat laterally. First abdominal segment slightly narrower than the following ones, the other abdominal segments almost equal in size; transverse tergal suture well developed.

Stenodictya lobata differs from spinosa in having longer thoracic segments, a narrower abdomen, less pronounced posterolateral angles on the tergites; and a broader forewing, which lacks the pronounced convex curve along the hind margin.

\section{Stenodictya spinosa (Brongniart)}

Figures 53, 54

Scudderia spinosa Brongniart, 1890: 6, pl. II, fig. 1.

Stenodictya lobata Brongniart, 1893: pl. 22, fig. 2 .

Brongniart's attempt to synonymize spinosa with lobata has already been noted. The original figure of specimen 22-2 showed some significant differences as compared with the type specimen of lobata, such as the size of the thoracic segments, the length of legs, the shape of the wings and the structure of the abdomen - all of which are certainly acceptable as the bases for specific differentiation in the Palaeodictyoptera. Sexual dimorphism, of course, can not be excluded as an explanation of these differences, spinosa obviously 

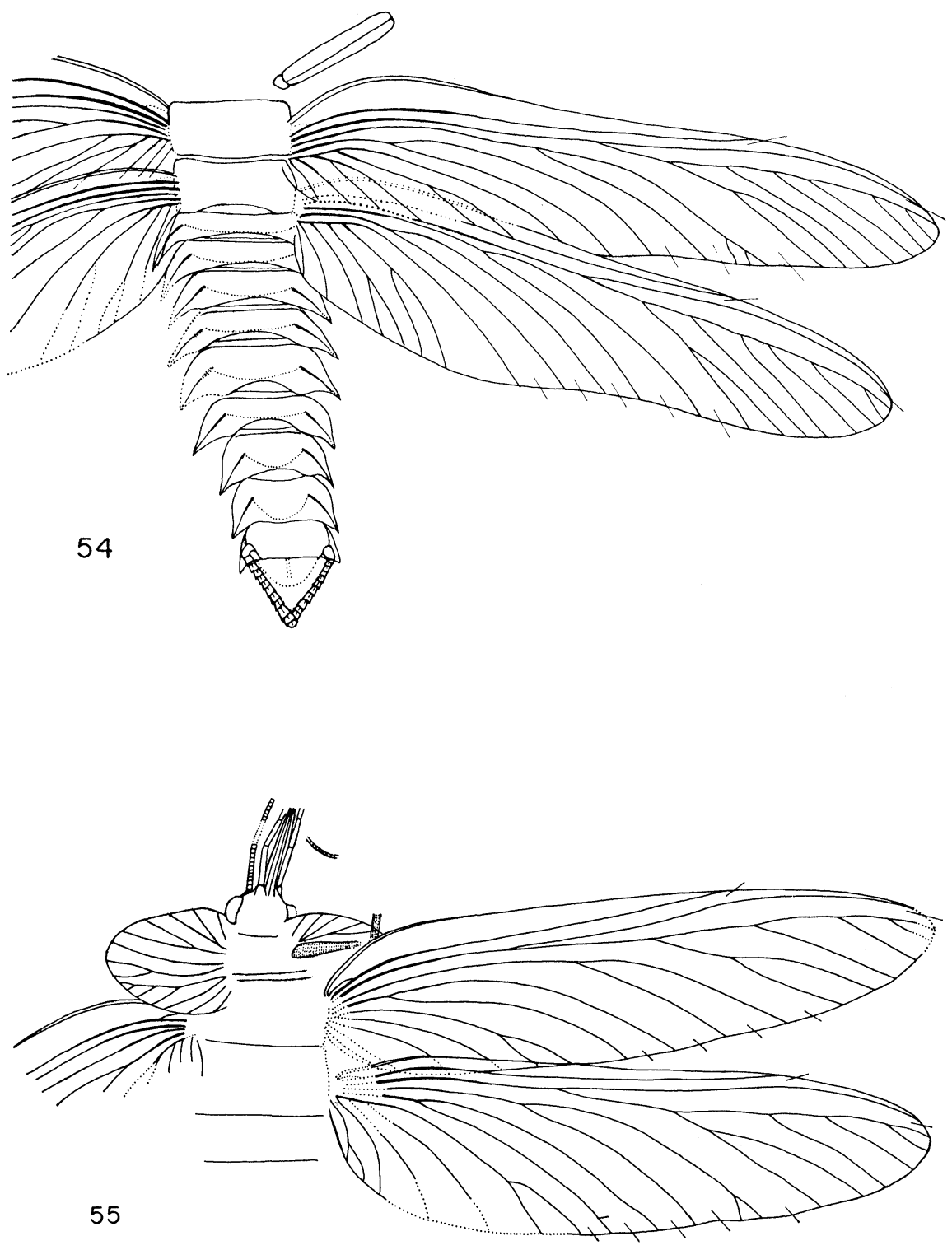

Figure 54. Stenodictya spinosa (Brongniart); specimen 22-2. Holotype. Figure 55. Stenodictya laurentiauxi sp. nov. Holotype. 
being a male and lobata a female; but since there is no information at all about the sexual dimorphism in the Palaeodictyoptera, I consider it preferable to retain Brongniart's spinosa as a distinct species.

Stenodictya spinosa represents the only male known of the Commentry Palaeodictyoptera with claspers preserved. A study of them under glycerin has added some further details. They are much more primitive than those of the Permian Megasecoptera (Carpenter, I939) and of the Permian and Recent Ephemeroptera. In both of these latter orders, the claspers are jointed at about the middle. The Palaeodictyoptera is the only known order in which the claspers are directed towards each other beyond the basal segment, which is slightly larger than the following ones.

The following account is based on specimen 22-2: Fore wing length 6r mm, width $\mathrm{I} 3 \mathrm{~mm}$. Anterior margin strongly convex proximally, very slightly concave at about mid-wing; posterior margin slightly concave from MP to $\mathrm{CuP}$. Apical part narrowed. Subcostal area broadened, narrowing abruptly towards the base. Rs with 6 branches, the first branch forked; anal area large with 6 veins, two of them forked. Hind wing: length $6 \mathrm{I} \mathrm{mm}$, width I $5 \mathrm{~mm}$.

Body structures: mesothorax $5.4 \mathrm{~mm}$ long, metathorax $4.5 \mathrm{~mm}$ long. Abdomen about $40 \mathrm{~mm}$ long. Abdominal segments unequal, segments one and two shorter than the following ones. First terpile $2.2 \mathrm{~mm}$ long, $19.6 \mathrm{~mm}$ wide; 5th tergite $5 \mathrm{~mm}$ long; 7 th tergite I I $\mathrm{mm}$ wide. Claspers $9.2 \mathrm{~mm}$ long.

The differences between the spinosa and lobata have been discussed above. From $S$. laurentiauxi spec. nov., spinosa differs in the narrower wings, especially in their distal portions by the preseore of the concavity along the posterior margin and by the more dictal origin of Rs.

\section{Stenodictya laurentiauxi sp. nov.}

Figures 55, 56

Stenodictya lobata Laurentiaux (nec Brongniart), 1952: 233-247, pl. 10, 10a.

The type specimen of this species has historical significance for the study of insect evolution. For many years the general belisf of the students of fossil insects was that the paleopterous orders of the Paleozoic, being generally primitive in nature and geologically old, must have had chewing mouthparts. The erroneous nature of this concept was apparent when Laurentiaux (1952) described the presence of a long, haustellate beak in the "classical" representative 


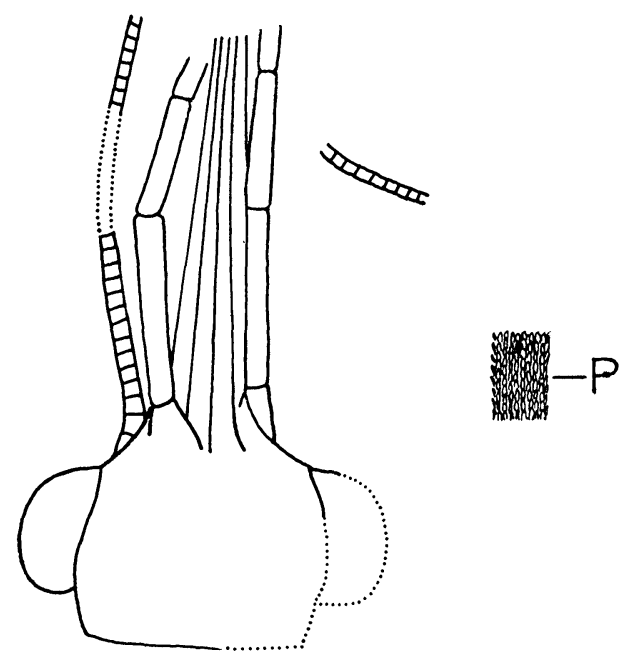

Figure 56. Stenodictya laurentiauxi sp. nov.; head, ventral view. P, surface of palpus, enlarged.

of the Palaeodictyoptera, Stenodictya, in a previously unstudied specimen which he found in the collections of the Sorbonne in Paris (subsequently deposited in the Institut).

Laurentiaux called attention to the similarities of the structure of the mouthparts of this specimen to that of Eugereon boeckingi Dohrn, from the Permian of Germany. He correctly concluded that the specimen as preserved shows the head and mouthparts from the ventral surface. Of all the specimens which I have seen, this is the only one showing the ventral view of the beak. The long palpi can be seen to arise beneath the stylets (more probably under the inner pair), which explains their close position to the base of the outer stylets when the beak is observed from the dorsal view in other specimens. The base of the beak itself is very indistinct so that other structures, such as the labium, cannot be distinguished. From my examination of the wings and body structures of the specimen which Laurentiaux described, I am convinced that this cannot be referred to lobata or spinosa and that it represents still another species. The formal description of this species, which I have the pleasure to name for Dr. Laurentiaux, Professor of Geology at Reims, is as follows: Fore wing length $64 \mathrm{~mm}$, width $\mathrm{I} 7 \mathrm{~mm}$. Anterior margin convexly curved at the base, then straight; posterior margin with a slight indentation at MP. Apical part broad, apex 
obtuse. Costal area only slightly broadened; Rs originating well before the middle of the wing, with four branches. Anal area small, with five branches. Hind wing length $64 \mathrm{~mm}$, width $\mathrm{I} 8 \mathrm{~mm}$. There are minor venational peculiarities in the wings of this fossil but these are almost certainly individual traits and not specific ones. For example the level of the division of $M$ is anterior to the origin of $\mathrm{Rs}$ in the fore wing but it is posterior to the origin of $\mathrm{Rs}$ in the hind wing.

Body structures: length of head $5 \mathrm{~mm}$, width about $9 \mathrm{~mm}$. Antennae composed of many short segments. The length of the beak, incompletely preserved, $8.6 \mathrm{~mm}$. The palpi orginate beneath the stylets, probably under the inner pair; segments of palpi with longitudinal, rugose ridges; first segment length $.8 \mathrm{~mm}$, ind 3.9 $\mathrm{mm}$ and $3 \mathrm{rd} 2.3 \mathrm{~mm}$.

\section{Stenodictya agnita (Meunier) \\ Figures 57, 58, 6I}

Microdictya agnita Meunier, 1908: 155; Meunier, 1908: 39, fig. 3; Meunier, 1909: 136, pl. 1, fig. 7 .

Stenodictya gaudryi Meunier, 1908: 139; Meunier, 1909: 42, fig. 2.

Stenod ctya fayoli Meunier, 1909: 134, pl. 1, fig. 5; Lameere, 1917: 153; Handlirsch, 1919: 4, fig. 2.

Stenodictya agnita Handlirsch, 1919: 3, fig. 6.

This species was based by Meunier on an isolated, incomplete fore wing with a well preserved archedictyon that forms numerous twigs. In the collections of the Institut in Paris I found another fore wing, completely preserved, which I am referring to the same species.

Comparing the type specimen of agnita with the type of fayoli (originally referred by Meunier to $S$. gaudryi Brongniart), I was unable to find any significant differences. Both the specimens are very similar in venation, in the details of the form of the posterior margin, in the nature of the archedictyon and the general shape of its cells. I am therefore synonymizing fayoli with agnita.

The following account is based on all three specimens of agnita.

Fore wing: length 70-74 mm, width I5.5-1 $8 \mathrm{~mm}$. Anterior margin convexly curved proximally, then almost straight. Posterior margin with two concavities between $\mathrm{IA}$ and $\mathrm{CuP}$ and at the end of $\mathrm{CuA}$. Apical part of wing gradually narrowing. R-rs area broad; Rs originating before mid-wing, with 4-6 branches; MP simple or with an additional branch. Anal area with six veins. Archedictyon dense, strong, forming extra twigs. Many anastomoses between cross veins. 

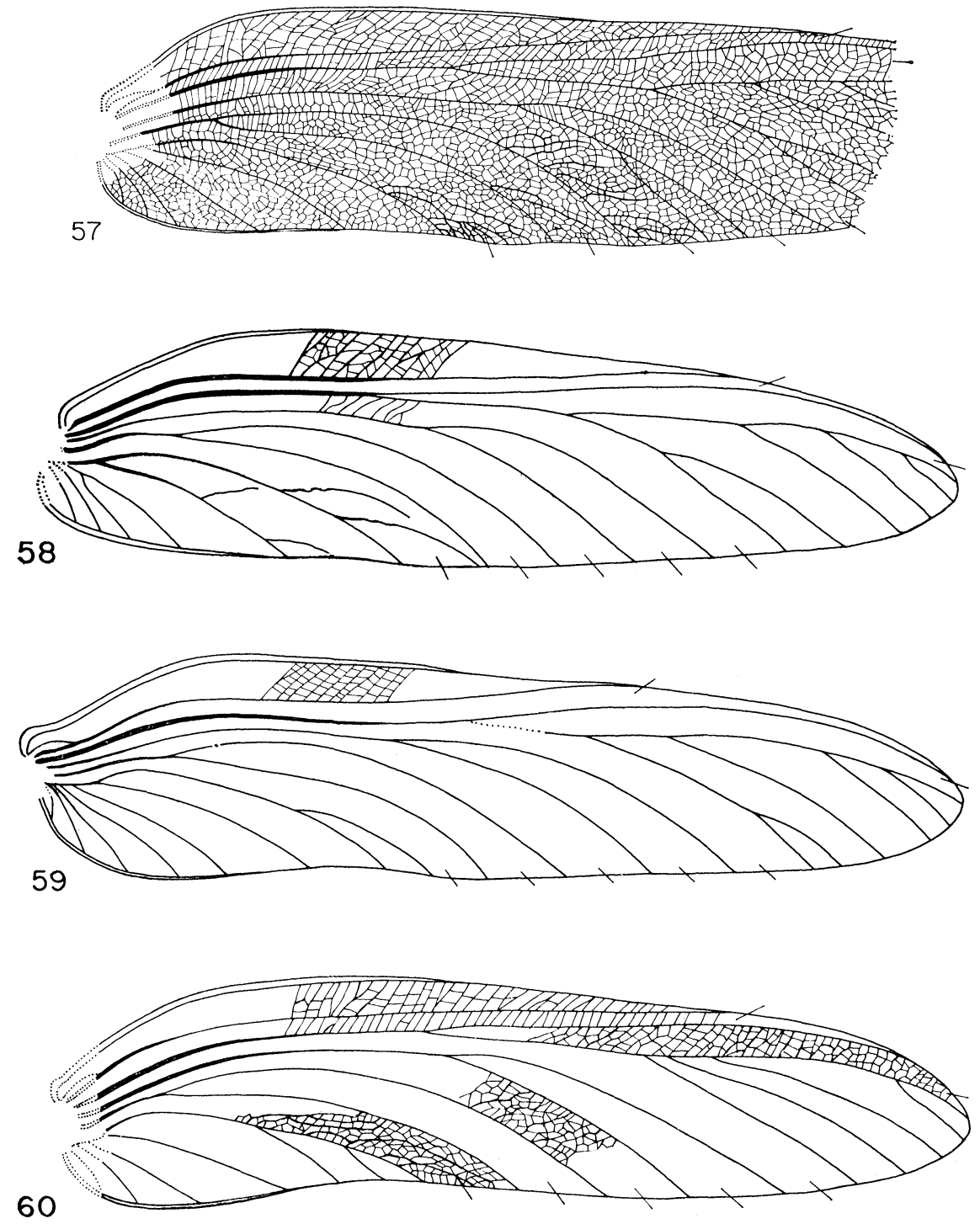

Figure 57. Stenodictya agnita (Meunier); fore wing. Holotype.

Figure 58. Stenodictya agnita (Meunier); fore wing.

Figure 59. Stenodictya perrieri Brongniart; fore wing, specimen 22-4.

Holotype.

Figure 60. Stenodictya perrieri Brongniart; fore wing. 
Body structures: Prothoracic lobes large, cordate, their 8 veins often forked and having numerous, irregular cross veins connected by anastomoses. Length of mesothorax $7.9 \mathrm{~mm}$. Legs relatively long, with slender tibiae, long tarsi and claws. Mesothoracic tibia $9.6 \mathrm{~mm}$ long; tarsus and claws combined II.03 mm; metathoracic tibia $12.4 \mathrm{~mm}$ long.

Stenodictya agnita is related to perrieri Brongniart from which it differs only in details of form of the posterior margin and in the more proximal origin of Rs. These two species may eventually turn out to be synonymous.

\section{Stenodictya perrieri Brongniart \\ Figures 59, 60}

Stenodictya perrieri Brongniart, 1893: 384, pl. 22, fig. 4; Handlirsch, 1906:

64, pl. 8, fig. 22; Handlirsch, 1919: 3.

This species was based by Brongniart on specimen 22-4, a complete fore wing. The cross veins in the subcostal area are more regular than shown in Brongniart's figure. I am referring to this species another undescribed fore wing, which differs from the type specimen in the more pronounced convex curvature of the posterior margin.

Fore wing: length $65 \mathrm{~mm}$, width $15 \mathrm{~mm}$. Anterior margin convexly curved basally, then almost straight. Posterior margin with pronounced convex curvature at the end of the basal third of the wing length, then straight. Apical part of wing moderately narrowing. Subcostal area relatively broad and short; Rs originating at the mid-wing, with 4 branches. Anal area large, with 7 branches.

As noted above this species is closely related to agnita from which it differs in the minor respects already noted.

\section{Stenodictya thevenini Meunier Figure 62}

Stenodictya thevenini Meunier, 1908: 154; Meunier, 1908: 37, fig. 1; Meunier, 1909: 133, pl. 1, fig. 2; Handlirsch, 1919: 5, fig. 5.

This species was based by Meunier on a perfectly preserved fore wing, distinct from any other known species of Stenodictya.

Fore wing: length $78 \mathrm{~mm}$, width I $8 \mathrm{~mm}$. Anterior margin very convex proximally, with a pronounced concavity just beyond midwing. Posterior margin slightly concave. Apical part of wing gradually narrowing. Sc extending far beyond mid-wing; Rs originating beyond first third of wing length, with four branches. Anal area large, with 5 veins. Archedictyon with elongate cells. 


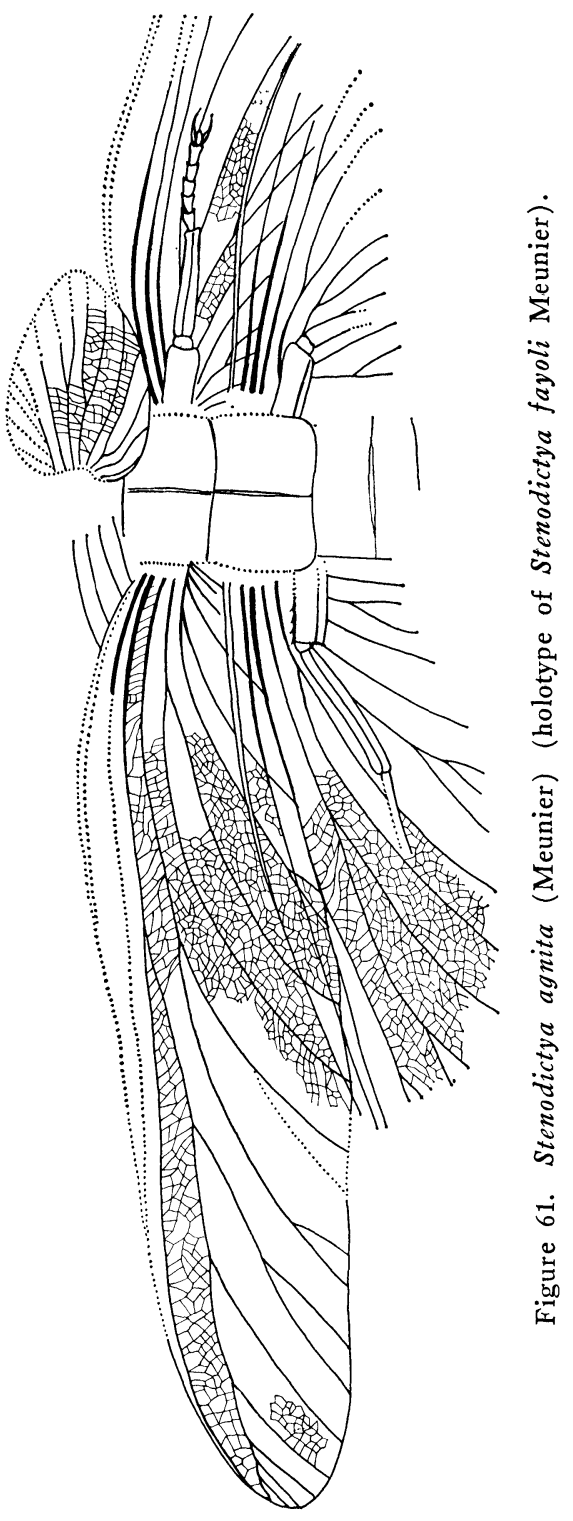


Stenodictya thevenini differs from all other known species by its very long and narrow wing, pronounced concavity of the anterior margin and the presence of elongate cells in the archedictyon.

\section{Stenodictya pygmaea Meunier \\ Figure 64}

Stenodictya pygmaea Meunier, 1911: 120, fig. 3; Meunier, 1912: 10, pl. 6, fig. 3; Handlirsch, 1919: 5, fig. 4.

This species was based by Meunier on a specimen consisting of fragments of fore and hind wings and on a perfectly preserved prothoracic lobe. The structure of the lobe, which is unusually broad and exceptional in the branching of its veins, would seem to justify the recognition of this specimen as a separate species.

The prothoracic lobe of the specimen of pygmaea, being unusually large and very well preserved, presents a rare opportunity to study this highly interesting structure of the Palaeodictyoptera in detail. Its narrow attachment, the shape of the lobe itself, the presence of veins and cross veins support Brongniart's conclusion about the homology of this structure with the functional wings. The lobes are attached to the prothorax along a cuticular thickening in the middle part of the base, from which the veins radiate. Actually, the nature of the attachment corresponds to that of the functional wings. Since the veins lack any trace of concentration along the costal margin ("costalization"), and since the base of the lobe shows no articular sclerites, the lobes probably never functioned as active organs of flight.

The venational pattern of prothoracic lobes does not completely follow Lameere's ( 1922 ) hypothetical scheme of the original venation of true wings, the veins ( $R, R s, M A, M P)$ always arising from the ridge separately, not from two common stems. This is true of all prothoracic lobes which I have been able to study. Nevertheless, the "cubitus" in almost all of the prothoracic lobes is very much like that of the functional wings, being characteristically S-shaped and two-branched. The number of branches arising from the cuticular ridge is variable and differs to some extent in each specimen. This is because in most specimens the twigs of "Sc" arise from the base separately and also because the number of independent "anal" veins varies. There is no homologizing of the veins by convexities and concavities, since, in all of the lobes which I have had the opportunity to study, the fluting is absent.

The independent origin of the branches of veins in the prothoracic lobes (excepting $\mathrm{Cu}$ and sometimes $\mathrm{Sc}$ ) seems to me to be a derived 

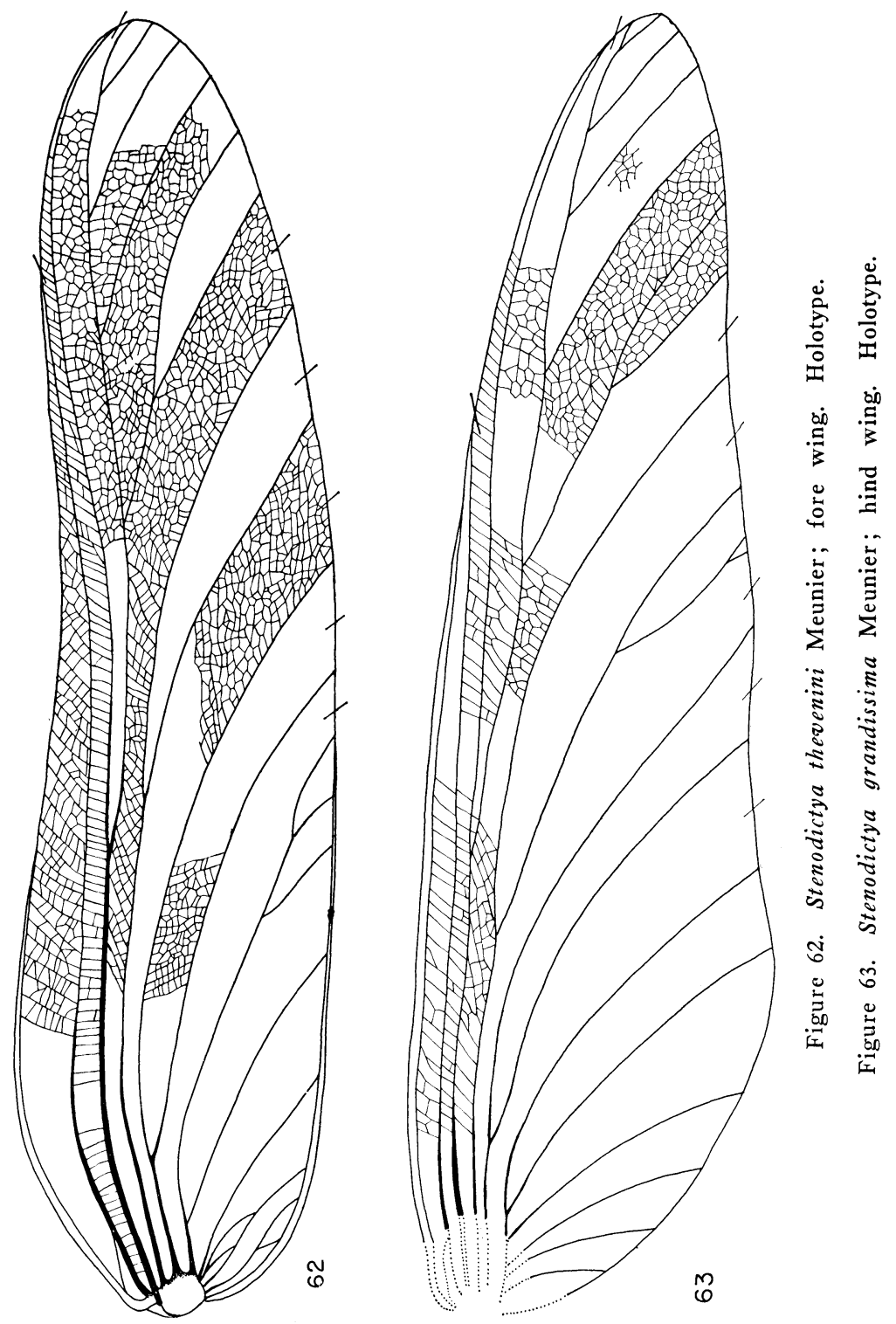
condition and not an original, primitive one. On the other hand, the almost symmetrical radiation of the veins in the lobes seems to indicate what was probably the original distribution of venation, before the veins were arranged more nearly longitudinally especially to support the anterior margin of the wing in connection with flight.

In figure $63 \mathrm{I}$ have attempted to identify the pronotal veins of pygmaea. Although Sc seems to be obvious by its position and its pectinate series of branches and $\mathrm{Cu}$ by its position and sigmoidal course, the designation of the other veins is purely arbitrary.

One of the surprising features of the prothoracic lobes is the extent to which they overlap the forewings. But in all probability the lobes were high on the prothorax, which was presumably rounded above, so that there was probably enough space for the movement of the fore wings without there being any interference by the lobes. At the same time, the lobes, which were attached along a very narrow ridge, were probably capable of being moved by the action of the fore wings or perhaps by air currents.

In the collections of the Institut there are several fragments of Palaeodictyoptera labeled by Meunier as Stenodictya pygmaea. These are so incomplete that they can only be referred to Dictyoneuridae inc. gen. The following account is based on the type specimen of pygmaea only. Fore and hind wings of the typical Stenodictya character. Body structures: prothoracic lobe, I $5 \mathrm{~mm}$ long, I $4 \mathrm{~mm}$ wide. Anterior and posterior margins strengthened near the base; the apex pointed, directed somewhat anteriorly. Veins of lobe radiating independently from a basal, cuticular ridge. Sc apparently sending out a pectinate series of 4 branches; " $R$ " and "Rs" simple; "MA" forked, directed above apex, "MP" simple, curved; $\mathrm{Cu}$ sigmoidal, dividing into " $\mathrm{CuA}$ " and "CuP", both of these being forked. One "anal" vein. Cross veins numerous, irregular, anastomosed. Prothoracic lobe sclerotized, covered by numerous deep pits.

\section{Stenodictya grandissima Meunier Figure 63}

Stenodictya grandissima Meunier, 1911: 121, fig. 4; Meunier, 1912: 11, pl. 7, fig. 5; Handlirsch, 1919: 3, fig. 1. Microdictya grandissima, Lameere, 1917: 159.

This species was based by Meunier on the largest wing so far known within the Dictyoneuridae. Lameere (1917, p. I59) believed that, because of the branched MP, this species should be referred to the genus Microdictya Brongniart, close to "Microdictya" 


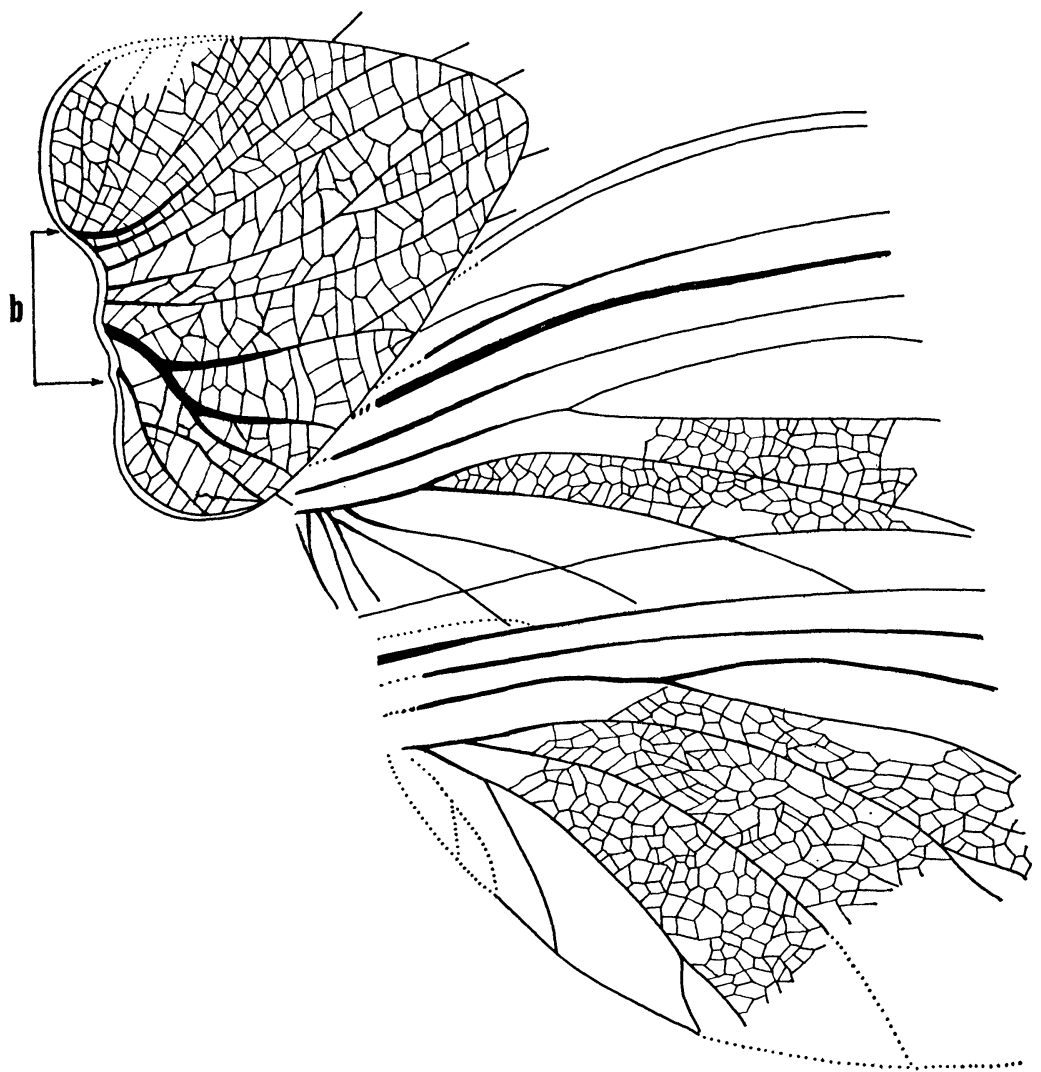

Figure 64. Stenodictya pygmaea Meunier. Holotype. Prothoracic lobe, basal parts of fore and hind wings; b, basal attachment of prothoracic lobe. 
agnita Meunier. However, this is not correct, because though both branches of $\mathrm{M}$ and $\mathrm{Cu}$ are usually simple in Stenodictya, additional twigs may be formed by the archedictyon. The triangular shape of the stenodictyid hind wing, which is very different from the oval shape of the microdictyid hind wing, with its narrow cubital area and simple $\mathrm{CuP}$, provides the more reliable basis for determining the generic position of grandissima.

\section{Stenodictya oustaleti Brongniart \\ Figure 65}

Stenodictya oustaleti Brongniart, 1893: 388, pl. 22, fig. 3; Handlirsch, 1906: 65, pl. 9, fig. 1; Handlirsch, 1919: 3.

This species was based by Brongniart on specimen 22-3, consisting of a complete hind wing, indistinct body and three legs. The legs are very well preserved, showing tiny tibiae, tarsal segments and short claws. Lameere ( I9I7, p. I 59) considered oustaleti synonymous with fritschi Brongniart. This may be so but it cannot be verified since the type and only known specimen of fritschi is fragmentary.

Hind wing: length $70 \mathrm{~mm}$, width $19.5 \mathrm{~mm}$. Anterior margin slightly convex proximally, then straight; posterior margin with slight concavity at $\mathrm{MA}$ and $\mathrm{CuA}$; apical part of wing long and narrow. Rs originating before mid-wing with six branches. Anal area large, with 6 veins, IA forked.

Body structures: legs short and stout, tibiae only a little longer and more slender than femora, with distinct spines; a deep suture extends across the femora proximally just before the end; tarsus stout, composed of 5 subequal segments; claws short. Mesothoracic femora $7 \mathrm{~mm}$ long, tibia $8.5 \mathrm{~mm}$ long and tarsus $8 \mathrm{~mm}$ long; metathoracic tibia Io $\mathrm{mm}$ long (incompletely preserved).

$S$. oustaleti differs from all other known species of the genus by the elongate and narrow apical part of the wing, by the numerous densely arranged branches of $\mathrm{Rs}$; it is somewhat similar to $S$. arnaudi Brongniart by the large anal area, with a forked IA.

\section{Stenodictya arnaudi Brongniart Figure 66}

Stenodictya arnaudi Brongniart, 1893: 385, pl. 22, fig. 6; Handlirsch, 1905: 64, pl. 8, fig. 23; Handlirsch, 1919: 3; Lameere, 1917: 158.

This species was based by Brongniart on specimen 22-6, a hind wing, lacking the apex. Lameere (1917, p. I58) noted that the hind wing of arnaudi could well belong to the same species as the 


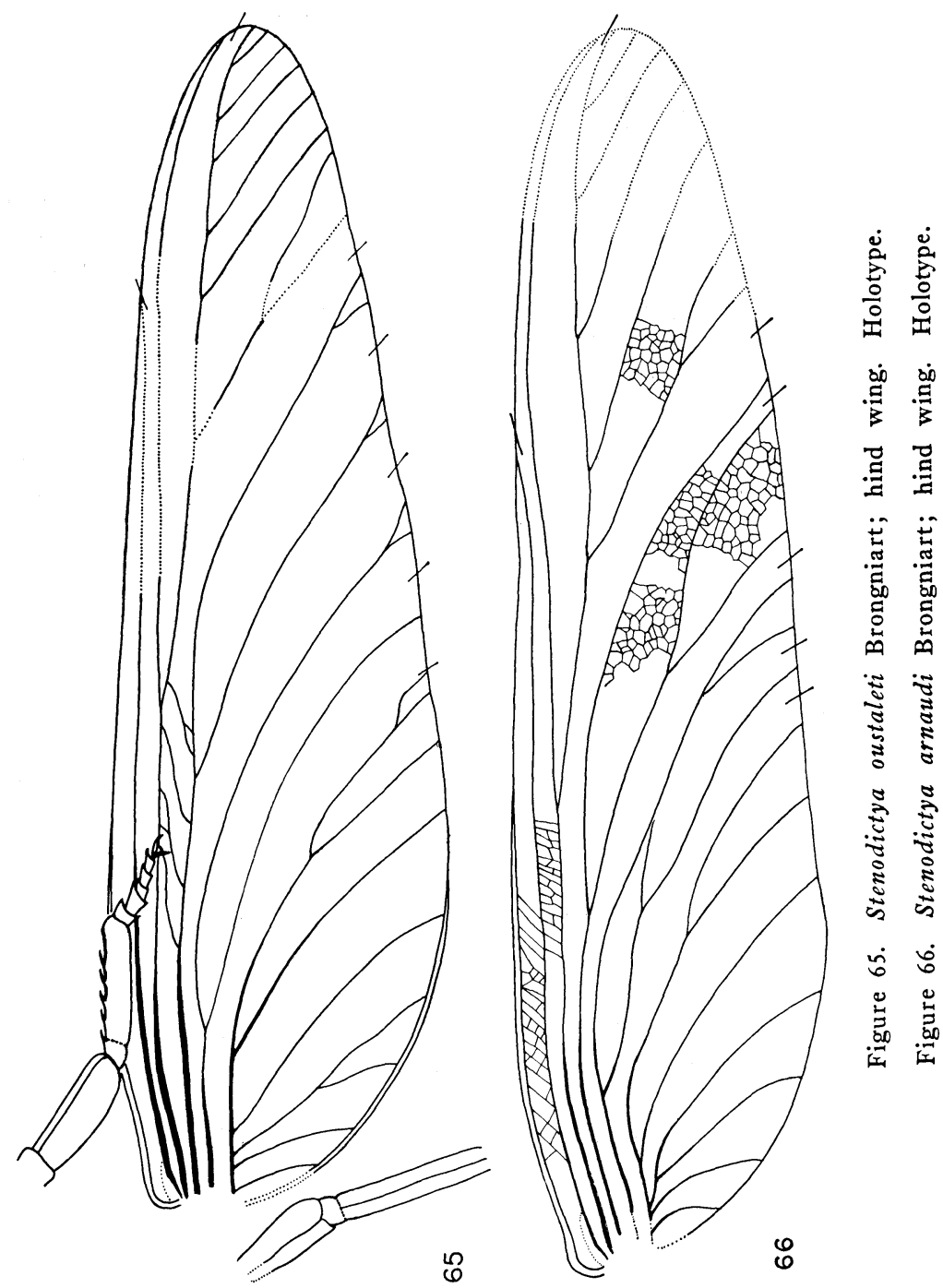


fore wing described under the name thevenini. This statement is not correct as thevenini has an unusual type of archedictyon, with elongate cells, and it also has a deeply concave anterior margin.

Hind wing: probable length $80 \mathrm{~mm}$, width $\mathrm{I} 8 \mathrm{~mm}$. Anterior margin slightly convex proximally and slightly concave just beyond the midwing; posterior margin convex at the end of $2 \mathrm{~A}$. Apical part of wing narrow and elongate. R-rs area broad; Rs originating well before mid-wing, with about five branches. $\mathrm{MP}$ and $\mathrm{CuA}$ giving rise to one irregular branch, probably secondarily formed by the archedictyon. Cubital area very narrow; course of $\mathrm{CuP}$ irregular. Anal area large with side branches, sometimes forked.

$S$. arnaudi differs from all other species by the irregular course of MP and CuP (which, of course, may be an individual trait only). It is similar to $S$. oustaleti in having a large anal area with IA forked.

\section{Stenodictya klebsi (Meunier) \\ Figure 67}

Microdictya klebsi Meunier, 1908: 154; Meunier, 1908: 38, fig. 2; Meunier, 1908: 135, pl. 2, fig. 1 .

Stenodictya klebsi Handlirsch, 1919: 6, fig. 7.

This species was based by Meunier on a complete hind wing. Unfortunately, I could not find the type specimen in the collection at the Institut. The accompanying figure was made from a very good photograph which Dr. Carpenter made in 1938 and in which all features are clearly visible.

Hind wing: length $72 \mathrm{~mm}$, width $2 \mathrm{r} \mathrm{mm}$. Anterior margin slightly convex proximally, then straight. Posterior margin with only a small convex curvature at IA. Apical part short and broadly rounded. Rs originating shortly before mid-wing, with 5 branches. Anal area large, with 4 veins, IA forking. Archedictyon with a tendency to form additional twigs.

$S$. klebsi has the broadest hind wing of all related species, especially in the apical part. Its outline resembles that of laurentiauxi sp. nov. and parisiana sp. nov.

\section{Stenodictya parisiana sp. nov.}

Figure 68

This species is based on a complete hind wing in the Institut collection. Its position is remote from the other species by the more advanced modification of the archedictyon into cross veins, which 

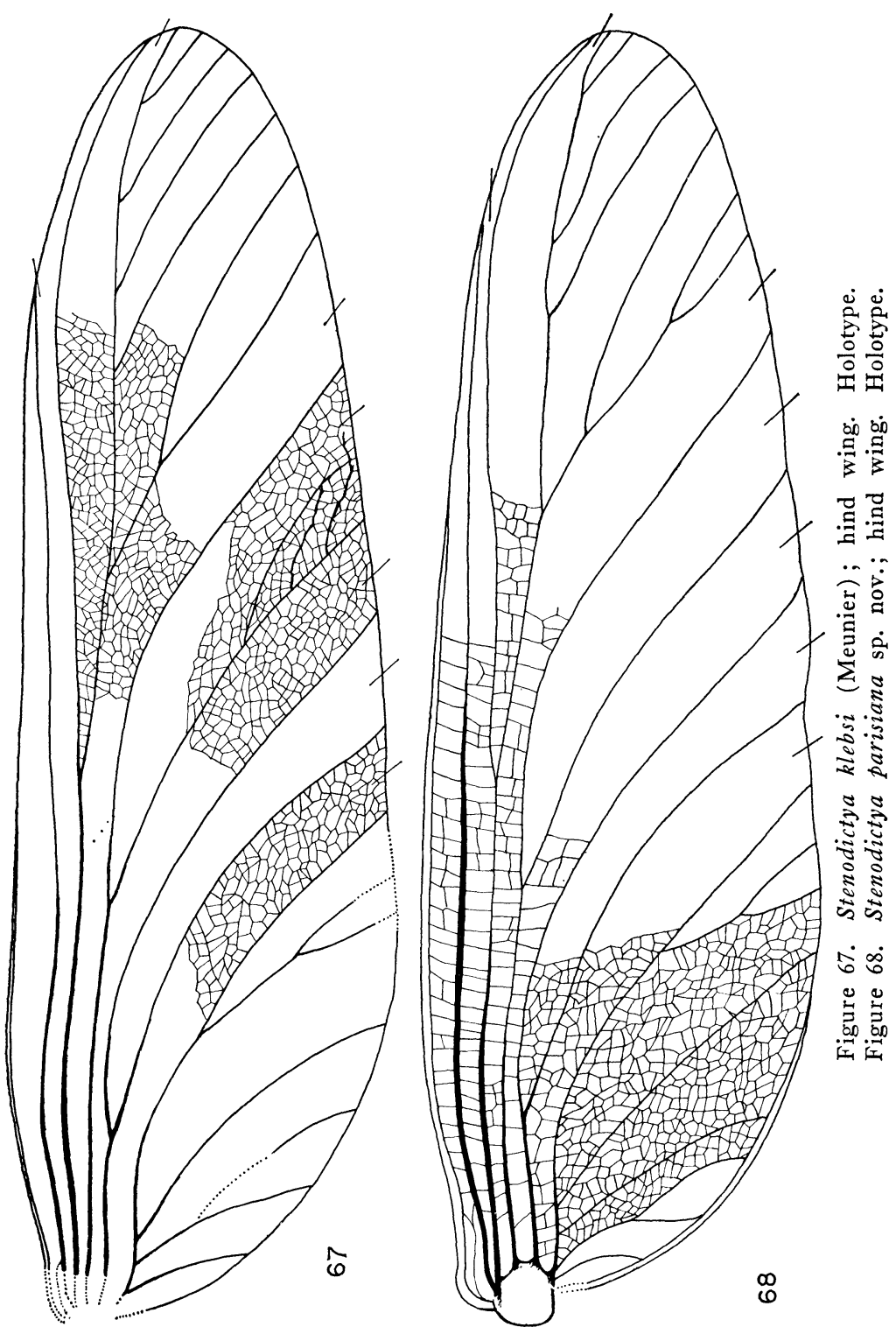
are relatively much less dense than in other species and which are oriented more perpendicularly to the axis of the wing.

Hind wing: length $56 \mathrm{~mm}$, width $16.5 \mathrm{~mm}$. Anterior margin very slightly convex, posterior margin with a small convex curvature at CuP. Apical part short and broad, broadly rounded. R-rs area broad. Rs originating shortly before the mid-wing, with 4 branches. Anal area large with 5 veins, $\mathrm{IA}$ forking. Cross veins in subcostal area, $\mathrm{r}-\mathrm{m}$ and $\mathrm{m}-\mathrm{cu}$ areas relatively sparse and almost perpendicular to the wing axis.

This species differs from all others in the genus by the smaller number of cross veins and by their arrangement on the wing. It is related to klebsi by its broadly rounded apex and forked IA.

\section{Stenodictya fritschi Brongniart \\ Figure 69}

Stenodictya fritschi Brongniart, 1893: 385, pl. 22, fig. 7; Handlirsch, 1906: 65 pl. 8, fig. 24; Lameere, 1917: 158; Handlirsch, 1919: 3.

This species was based by Brongniart on specimen 22-7, represented by a fragment which does not show enough features to enable comparison with the other species of the genus. It is probably part of a hind wing; the length of the fragment is $38 \mathrm{~mm}$, the width $20 \mathrm{~mm}$. The wing probably narrowed gradually towards the apex; the anal area had a forked IA. The species may be related to Stenodictya with broad wings, such as klebsi.

Two additional fragments of hind wings are included in the collection at the Institut. These are too incomplete to justify formal description but figures of them are included here because they show a few features not noted in other species. One of these (figure 70) is a fragment (Stenodictya sp. A) which shows clearly the basal subcostal plate and the branching of $2 \mathrm{~A}$, which is probably an individual variation. The anal area has 5 veins, $\mathrm{IA}$ is forked and $2 \mathrm{~A}$ has three branches arising pectinately. Wing fragment $37 \mathrm{~mm}$ long and $2 \mathrm{I} \mathrm{mm}$ wide.

The other specimen is a fragment of a hind wing (Stenodictya sp. B), which I could not find in the Institut but which was photographed there by Dr. Carpenter in 1938. The accompanying drawing (Figure 7I) was made from the photograph. Rs originates shortly before mid-wing, MP has one additional branch. The anal area is large with 6 veins and $\mathrm{IA}$ is forked twice. The archedictyon is irregular and dense. 

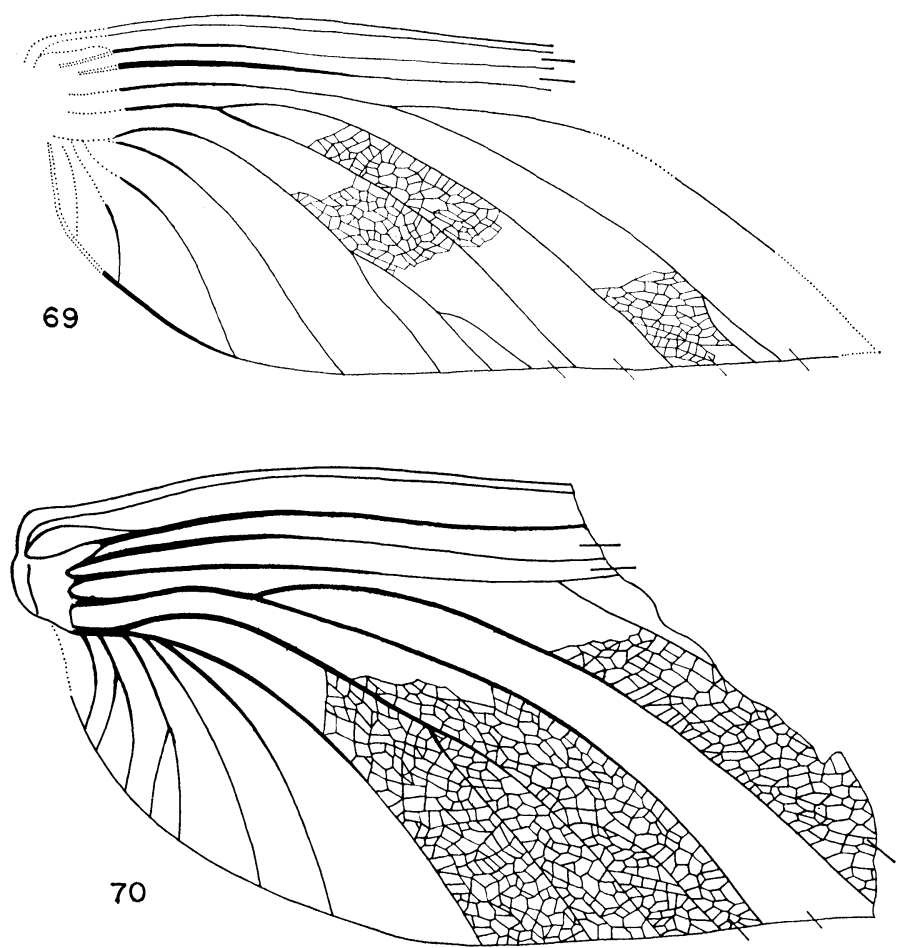

Figure 69. Stenodictya fritschi Brongniart; specimen 22-7; hind wing fragment. Holotype.

Figure 70. Stenodictya sp. Hind wing. 


\section{Microdictya Brongniart}

Heeria Brongniart, 1893: 338.

Microdictya Brongniart, 1893 (pro Heeria Brongniart, nec Scudder, 1890)

(Atlas) : 28; Handlirsch, 1919: 6; Lameere, 1917: 159.

Type species: Heeria vaillanti Brongniart, SD Handlirsch, I922.

Brongniart established the genus Heeria on two species, vaillanti and hamyi but in a foot-note of the same publication ( 1893, p. 28, Atlas) he changed the name to Microdictya because of the homonymy indicated above.

This genus includes less specialized species than Stenodictya, with richer venation and with the archedictyon much more developed. Both pairs of wings are more alike in shape than in Stenodictya. Bolton (1917, p. 9) was of the opinion that Microdictya and Sagenoptera Handlirsch were junior synonyms of Goldenbergia Scudder, I885. Although this is possible, I am not recognizing this synonomy at this time; it is necessary that the specimens on which Goldenbergia were based be examined with special reference to this question.

The characteristics of Microdictya are as follows: wings very much alike in shape and venation. Fore wings usually broadest at about mid-wing; anterior margin convex near the base; precostal strip pronounced; postcostal vein short, simple, terminating on Sc. Sc not reaching the apical part of the wing; Rs originating before the end of the first third of the wing length; MA simple, MP branched twice, $\mathrm{CuA}$ simple, $\mathrm{CuP}$ branched once or twice. Anal area narrow with three to five pectinate branches. Hind wings a little broader, usually with the posterior margin slightly convex. The hind wing broadest at about mid-wing. Anal area a little broader than in the fore wing. Archedictyon very irregular, changing into irregular cross veins with many anastomoses in subcostal and sc-r areas. Wing membrane, veins and archedictyon with a dense covering of pits.

Microdictya differs from Stenodictya in having both wings broadest at about the middle, in having MP and $\mathrm{CuP}$ branched, the anal area narrower and by the generally oval shape of the wings.

Species included in Commentry shales: Microdictya vaillanti Brongniart, I893; Microdictya hamyi Brongniart, I893; Microdictya lacroixi Meunier, I910; Microdictya villeneuvei Meunier, I908. 

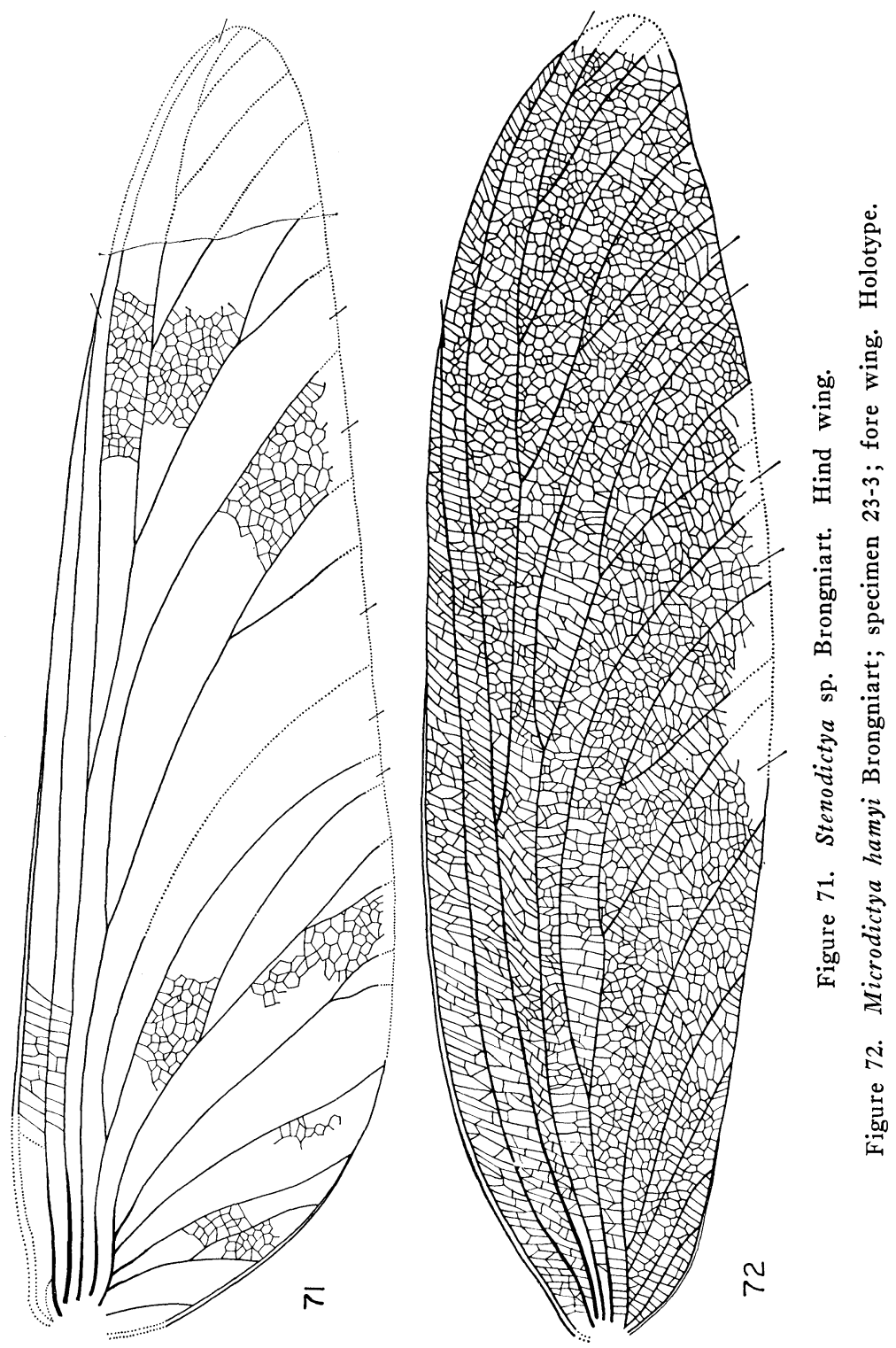


\section{Microdictya vaillanti (Brongniart)}

\section{Figures $73,74,75$}

Heeria vaillanti Brongniart, 1893: 389.

Microdictya vaillanti Brongniart, 1893, Atlas: 28, pl. 22, fig. 12, pl. 23, fig. 1, 2; Handlirsch, 1906: 65, pl. 9, fig. 6; Lameere, 1917: 159; Handlirsch, 1919: 6.

Stenodictya gaudryi Brongniart, 1893: 384, pl. 22, fig. 5; Handlirsch, 1906: 64, pl. 8, fig. 21; Handlirsch, 1919: 3.

This species was based by Brongniart on two specimens: 23-I (and its counterpart 23-2), an incomplete body and four remarkably preserved wings; and 22-I2, a fore wing with a small fragment of a hind wing. I designate specimen 22-12 (figure 72) as the lectotype of vaillanti, since the other specimen is not present in the collection of the Institut in Paris and is presumed lost. The figure of that fossil (figure 73) included here is based on an excellent photograph of it made by Dr. Carpenter in 1938 ; in the photograph, all features of the wings, including the archedictyon, are perfectly clear. The body (best preserved in the reverse half of the fossil) shows the head, prothoracic lobes and part of the abdomen but unfortunately I was not able to work out these details reliably enough from the photograph for inclusion in the drawing.

Specimen 22-5, described by Brongniart in 1893 as gaudryi (figure 74) is clearly vaillanti. The fore wing is very faintly preserved and Brongniart, with the methods he used, was unable to see the characteristic branches on MP and $\mathrm{CuP}$, which do become distinct under glycerin.

The characteristics of vaillanti are as follows: fore wing, length 60 to $70 \mathrm{~mm}$, width $\mathrm{I} 5$ to $18 \mathrm{~mm}$. Fore wing oval, broadest at about mid-wing; anterior margin slightly convex; posterior margin slightly concave. Rs originating well before mid-wing, with four branches. MP giving rise to two branches, $\mathrm{CuP}$ with one or two branches. Anal area narrow, with four veins, some of them forked. Archedictyon denser than in most other species, the components bordering the cells irregular, giving the cells the character of a "loose" network. Hind wing, width I6.5- $19.5 \mathrm{~mm}$. Posterior margin slightly more concave.

Microdictya vaillanti is related to hamyi in having a dense archedictyon but differs in having the veins directed more obliquely and by having narrower $\mathrm{rs}, \mathrm{m}$ and $\mathrm{cu}$ areas. From lacroixi Meunier, which has a similar shape of hind wing and similar venation, it differs in the much denser archedictyon. 


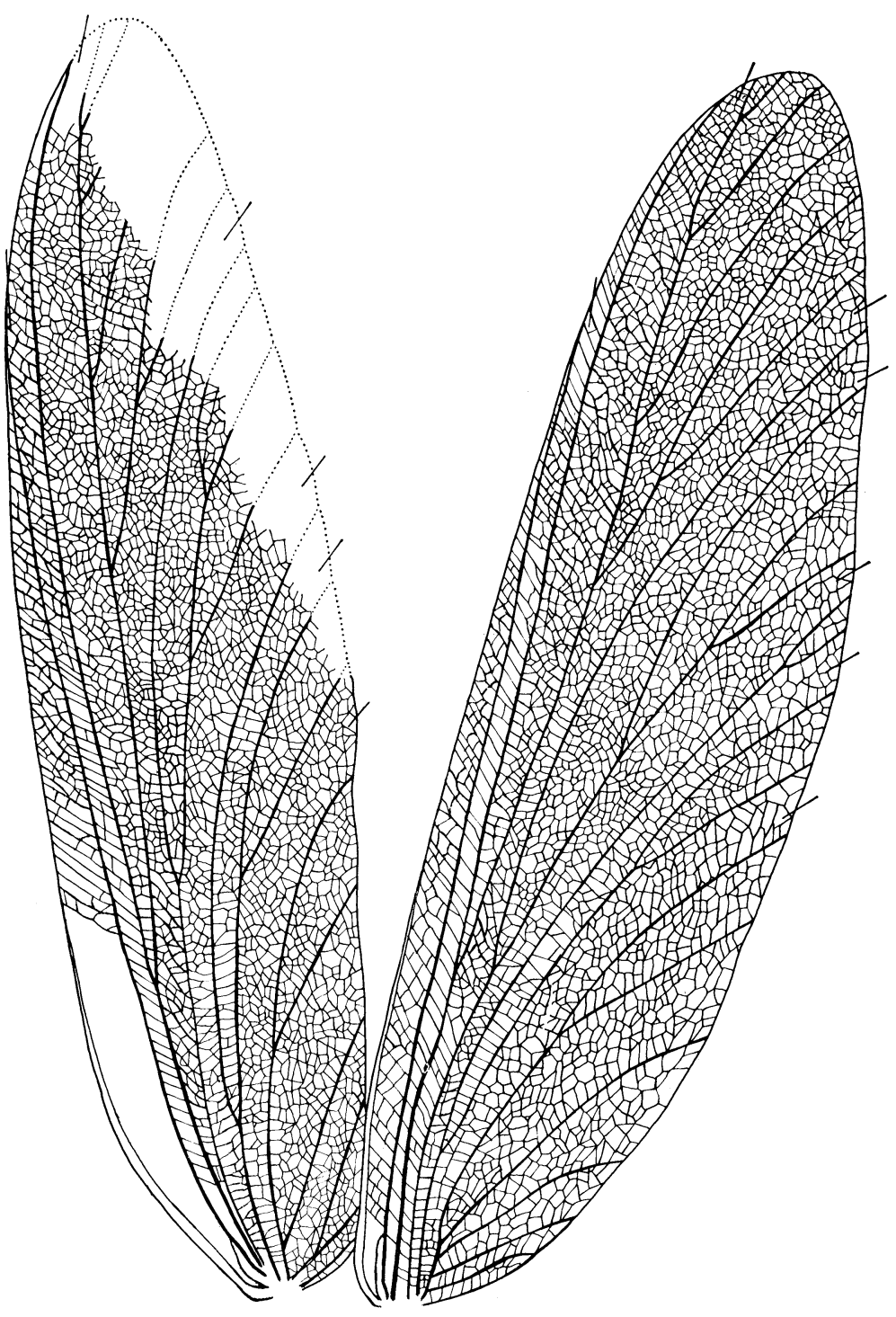




\section{Microdictya hamyi (Brongniart)}

Figure 72

Heeria hamyi Brongniart, 1893: 390.

Microdictya hamyi Brongniart, 1893: 390, pl. 22, fig. 3; Handlirsch, 1906: 66, pl. 9, fig. 7; Handlirsch, 1919: 6.

This species was based by Brongniart on two well preserved fore wings of specimen 23-3. Bolton ( 1917, p. 8) identified as the same species a fragment (apical part of a wing), from Commentry and now in the Mark Stirrup collection in Manchester. This probably does belong to Microdictya but its specific position is obscure.

Fore wing: length $80 \mathrm{~mm}$, width $22 \mathrm{~mm}$. Fore wing almost oval in shape, broadest at about mid-wing. Apex of wing directed posteriorly. Apical part of wing relatively broad and short. Subcostal area narrow, almost band-like; Sc-r area very broad, Rs originating not far before mid-wing, with four branches. MP and $\mathrm{CuP}$ with two branches. Cup-Ia area very broad. Anal area long, narrow, with 5 anal veins. Branches of $M$ and $\mathrm{Cu}$ strongly curved towards the posterior margin. Archedictyon dense.

This species differs from all others by the convex curvature of $\mathrm{M}$ and $\mathrm{Cu}$ branches towards the posterior margin and by the broad cup- $I$ a area. The archedictyon is almost as dense as in vaillanti but less irregular, tending to be arranged into cross veins.

\section{Microdictya lacroixi Meunier}

\section{Figure 76}

Microdictya lacroixi Meunier, 1910: 235, fig. 2; Meunier, 1912: 6, pl. 6, fig. 2; Handlirsch, 1919: 6, fig. 8.

This species was based on a well preserved hind wing with a relatively sparse archedictyon. Unfortunately, I could not locate the type of this species in the Institut; the figure included here was made from Dr. Carpenter's I938 photograph.

Hind wing: length: $5 \mathrm{I} \mathrm{mm}$, width $15 \mathrm{rnm}$. Anterior margin almost straight; posterior margin regularly curved. Hind wing broadest shortly before midwing. Rs originating well before apex, with 3 branches, first of them forked three times. MP reaching the posterior margin with its 3 branches. CuP giving rise to one branch. Anal area long and narrow, with 5 pectinate branches. Archedictyon sparse, more in the form of irregular cross veins connected by anastomoses.

Microdictya lacroixi is related to villeneuvei by its sparse archedictyon but differs in wing shape. From the other species with similar wing shape, it differs in the archedictyon. 

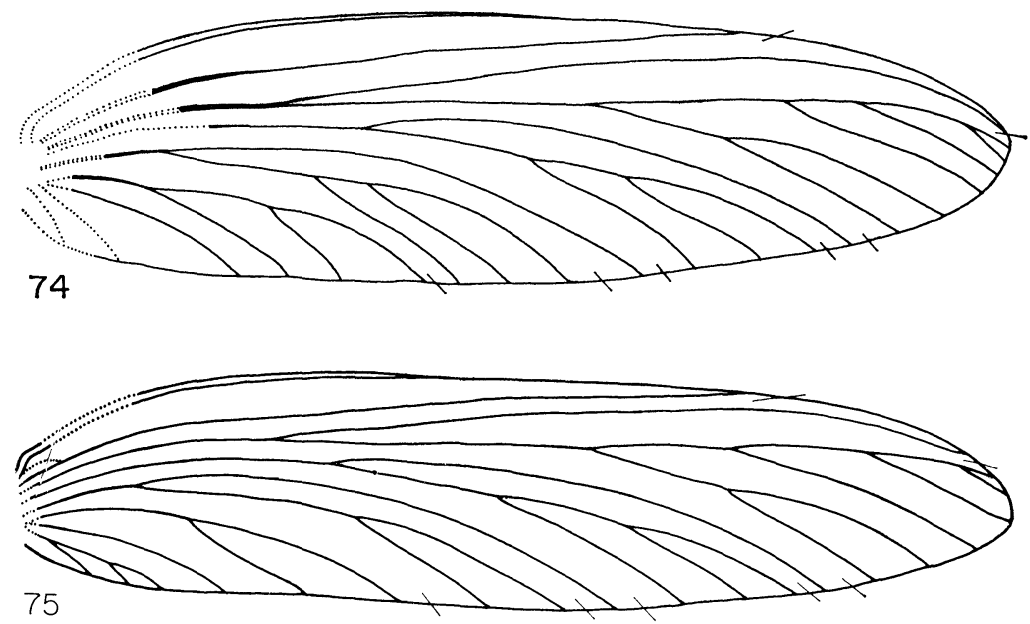

Figure 74. Microdictya vaillanti Brongniart; specimen 22-12; fore wing. Holotype.

Figure 75. Microdictya vaillanti Brongniart; specimen 22-5; fore wing. (Type of Stenodictya gaudryi Brongniart).

\section{Microdictya villeneuvei Meunier \\ Figure 77}

Microdictya villeneuvei Meunier, 1908: 245, fig. 1; Meunier, 1908: Meunier, 1909: 136, pl. 1, fig. 4; Handlirsch, 1919: 6, fig. 9.

This species was based on a hind wing, which lacked the apex; the type could not be found in the collection of the Institut and the figure included here was made from Dr. Carpenter's photograph.

This species represents the most specialized one within the genus Microdictya. The development of veins along the costal area is very advanced and the outline of the hind wing, recalling some species of the related genus Stenodictya, has a pronounced convex curvature of the posterior margin in the apical half. At the same time, the proximal half of the wing retains the oval shape characteristic of other species of the genus.

Hind wing: length $50 \mathrm{~mm}$, width $\mathrm{I} 4 \mathrm{~mm}$. Wing broadest shortly before mid-wing. Anterior margin convex near the base, slightly concave at about mid-wing. Posterior margin concave in proximal half, then forming a pronounced convex curvature at the end of the first branch of MP. Apex apparently directed backward. Rs long, originating before the first third of the wing length. MP and $\mathrm{CuP}$ giving off two branches. Anal area long and narrow, with four 

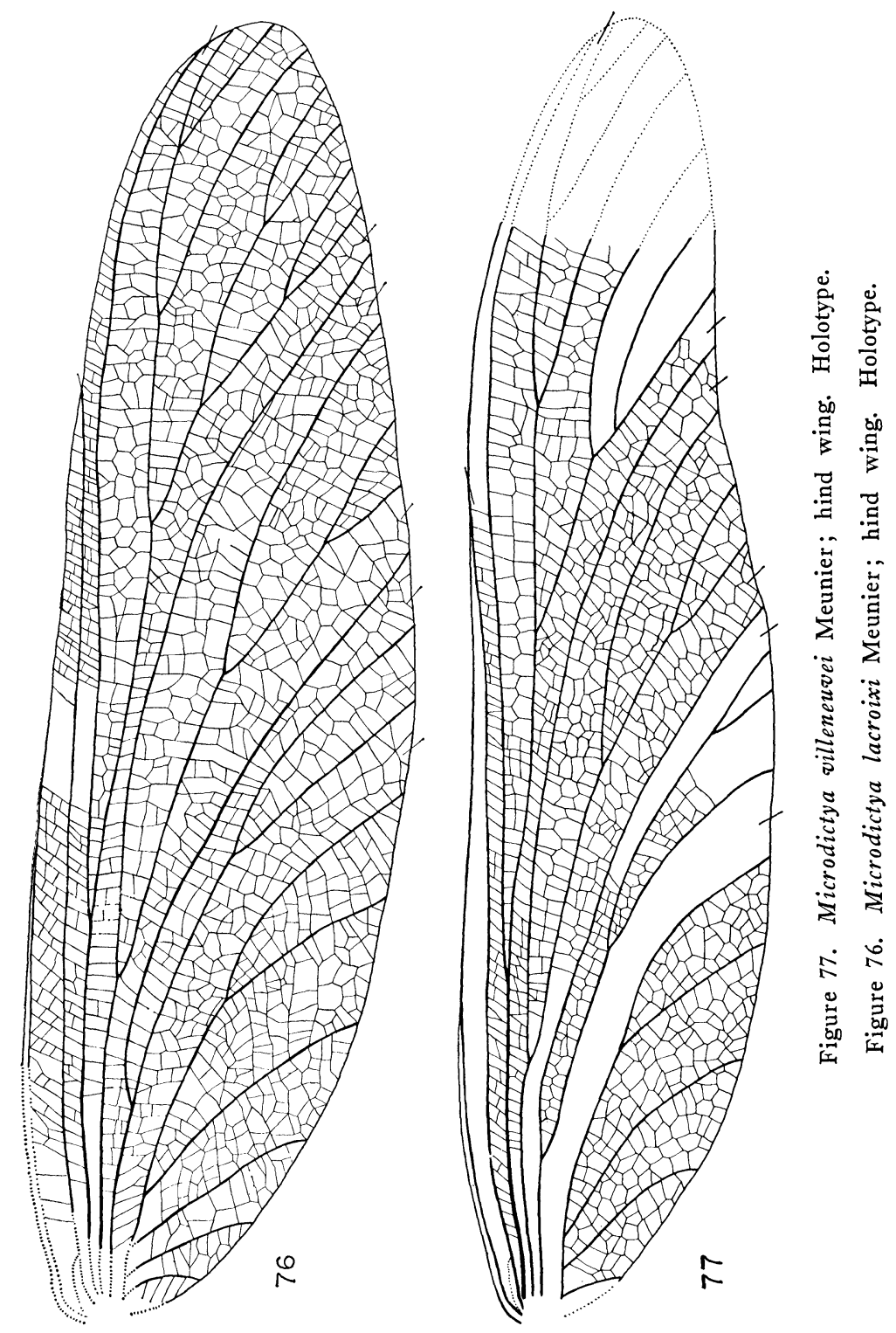
veins. Archedictyon sparse, more like irregular cross veins connected with anastomoses.

Microdictya villeneuvei differs from all other species in the pronounced curvature of the distal part of the posterior margin.

\section{Summary}

The Commentry shales in central France provide us with the most extensive and the best preserved collection of Palaeodictyoptera so far known. The information obtained from detailed study of these fossils shows that this extinct order was a very diverse one, with far more specialization and adaptations than have previously been suspected. The following is a general account of the structure of the Palaeodictyoptera, as it is now known.

The head was small, often very small, with slender antennae composed of numerous segments. The eyes were large and conspicuous. The mouthparts were haustellate, forming a prominent beak, resembling superficially that of the Hemiptera. However, the head was not opisthognathous but clearly hypognathous, perhaps with a tendency towards the prognathous condition: the beak is preserved in the fossils in front of the head, projecting somewhat obliquely in an anterior-ventral direction. Four long stylets were included in the beak, their basal portions being covered by a triangular or lanceolate labrum. The clypeal region was markedly swollen and enlarged, much as in the Hemiptera, and possessed a median longitudinal ridge as well as several transverse ridges. It seems almost certain that this enlarged clypeal region marked the presence of a sucking pump. The stylets were apparently held tightly together but were probably moveable, to some extent. The palpi, presumably the maxillary pair, were slightly longer than the beak and were attached to the head laterally at the base of the beak. The palpi were segmented, six segments being present in specimens in which the details can be ascertained; the first segment as well as the last one or two segments were much shorter than the others. The surface of the palpi was rugose. The beak itself was from 2 to $2.5 \mathrm{~cm}$ long in the moderate to large Palaeodictyoptera although in one such species (Lycocercus goldenbergi) the beak was only $\mathrm{I} \mathrm{cm}$ long. In smaller specimens, such as some spilapterids, the beak was correspondingly shorter.

The thoracic segments were nearly equal in size, though the prothorax was frequently somewhat shorter and sometimes narrower than the others. A median, longitudinal ridge was often present. 
The prothorax possessed a pair of lobes, which were usually cordate, and which were narrowly attached to the pronotum along a cuticular ridge. In most cases the lobes appear to have been membranous and to have possessed longitudinal as well as cross veins; the veins arose from the basal cuticular ridge and radiated into the lobe, some of them branching. In the fossils the convexities and concavities of the veins are not visible, and they were presumably not present in the original specimens. In exceptional instances, the lobes may be heavily sclerotized, all traces of the veins being lost. The lobes usually overlap the basal parts of the fore wings to a considerable extent; being situated high on the prothorax, they may have acted as immovable "fore sails", air passing under them and increasing the pressure on the functional wings. Prothoracic lobes of the Palaeodictyoptera were undoubtedly homologous with the functional wings; there is no evidence that they were used for active flight, the basal articulation and the distribution of the veins being unlike those of the functional wings.

The legs of the Palaeodictyoptera were relatively short or even very short and usually stout. The tibiae were slightly elongate, often spiny, and the tarsus was composed of five, subequal segments; two claws and an arolium were present in at least some species. The tibiae in some specimens show what appears to be a separate segment proximally, set off by a suture from the rest of the tibia; this seems to be comparable to the structure of the tibia in many existing Ephemeroptera. The three pairs of legs are similar except that the hind pair are slightly longer. The legs so far as known were adapted for walking and presumably were also used for holding onto vegetation or for climbing.

The wings of the Palaeodictyoptera had great diversity in size and shape. There are some species in which both pairs of wings were almost equal, others in which the hind wings were somewhat enlarged and then still others in which the hind wings were greatly enlarged. In several isolated lines of families, there was a tendency for the hind wings to be reduced, with respect to both width and length or a combination of both. The shape of the wing also extends over a very wide range, from relatively short to very long and slender. The articulation of the wings with the thorax is not preserved in detail in any specimens but it seems to be comparable to that in the existing Palaeoptera, the Ephemeroptera and Odonata. The convexity and concavity of the longitudinal veins is well known in the Palaeodictyoptera; a postcostal or a precostal area is present 
at the base of both pairs of wings. There are also present in the basal part of the wings (especially if they are long or thin) transverse, supporting structures, generally in the form of cuticular thickenings, supporting cross veins or dark sclerotized bands. In some species there is a deep, oblique furrow crossing the basal part of the anal area and forming a line along which the wings appear to break readily; the function of this structure is not knorvn.

The wings are often dark in color, with transverse light bands or with small, circular spots in varied patterns of distribution. There are also circular, cuticular thickenings on the wing membrane, which may have been the site of macrotrichia with a sensory function. The precostal strip, bordering the costa for varying lengths, is serrated in some species, as it is in the existing Odonata. The palaeodictyopterous wings were apparently consistently hairy, at least along the veins; the cross veins, the elements of the archedictyon and the wing membrane itself between veins also had hairs in some species. Sometimes long hairs formed clusters at the base of the wing and along the wing margin (recalling the subimaginal condition of some mayflies) or on the wing membrane.

The abdomen was always shorter than the wing but, with few exceptions, it was not excessively broad. Often, the lateral parts of the tergites of the abdomen were separated from the main part of the tergum by a longitudinal suture, rescmbling in general the structure of the lateral lamellae of some mayfly nymphs. In a few cases, the tergites were strongly sclerotized, with lateral expansions, having oblique ridges along the expanded portions. The females had a robust ovipositor, usually curved but not really elongate. The general nature of the ovipositor resembled that of the Recent Zygoptera and some Anisoptera. The males of at least some Palaeodictyoptera had short but distinct claspers, apparently segmented, and arising from the ninth segment. The aedeagus was paired, at least in the few specimens in which this structure was preserved; a similar condition is known in the Protohymenidae of the Megasecoptera. Both males and females of the Palaeodictyoptera possessed long, robust, multisegmented cerci, approximately twice as long as the abdomen.

Very little is known about the nymphs of the Palaeodictyoptera. The evidence, such as it is (Carpenter and Richardson, 1969, p. 309), indicates that the nymphs were terrestrial and, like the adults, had haustellate mouthparts. The wing pads of the nymphs were held in oblique-lateral positions, independent of each other in all stages and 
apparently articulated to the thorax in the same manner as were the wings. There is no evidence as to whether or not a subimaginal stage was present.

The Palaeodictyoptera, one of the most abundant and widely distributed orders of the oldest winged insects, apparently inhabited lowland of forests of the Upper Carboniferous and Lower Permian periods. It is clear from their haustellate mouthparts that they fed on liquid food only, this being almost certainly of plant origin. It is conceivable that the basic change in the plant life, which took place in the lower part of the Permian, may have been the principle reason for the extinction of this order of insects, along with the Megasecoptera and Diaphanopterodea, whereas the other contemporary paleopterous orders with chewing mouthparts, Ephemeroptera and Odonata, were able to survive the changes.

\section{REFERENCES \\ This list includes the literature cited in all three parts of this series of papers.}

Agnus, A. N.

1902. Description d'un Névroptère fossile nouveau. Homoioptera gigantea. Bull. Soc. Ent. Fr. 1902: 259-261.

BoLton, $\mathrm{H}$.

1917. On Some Insects from the British Coal Measures. Quart. Journ. Geol. Soc. 72: 43-62.

Borre, A. P.

1875. Note sur des empreintes d'insectes fossiles, découvertes dans les schistes houillers des environs de Mons. C. R. Soc. Ent. Belg., (2) 12: 4-7.

1875. Complément de la note sur des empreintes d'insectes fossiles. C. R. Soc. Ent. Belg., (2) 13: 7-11.

Brauer, F.

1886. Ansichten über die palaeozoischen Insekten und deren Deutung. Ann. Naturh. Hofmus. Wien. 1: 87-125.

BRONGNIART, C.

1883. Note sur les insectes fossiles de Commentry. C. R. Soc. Geol. Fr., $1883: 15-16$.

1883. Aperçu sur les insectes fossiles en général et observations sur quelques insectes des terrains houiller de Commentry. Le Naturaliste, $5: 266-268$.

1885. Les insectes fossiles des terraines primaires. Bull. Soc. Rouen. 1885: $50-68$.

1890. Note sur quelques insectes fossiles du terrain houiller qui présentent au prothorax des appendices aliformes. Bull. Soc. Philomat. Paris, sér. 8, 2(3): 154-158.

1893. Recherches pour servir a l'histoire des insectes fossiles des temps primaires. $493 \mathrm{pp}$. Atlas, $44 \mathrm{pp}$. [thesis]. 
Carpenter, F. M.

1938. Two Carboniferous Insects from the Vicinity of Mazon Creek, Illinois. Amer. J. Sci. (5) 36: 445-452.

1939. The Lower Permian Insects of Kansas. Part 8. Additional Megasecoptera, Protodonata, Odonata, Homoptera, Psocoptera, Protelytroptera, Plectoptera, and Protoperlaria. Proc. American Acad. Arts Sci. 73 (3) : 29-70.

1944. Carboniferous Insects from the Vicinity of Mazon Creek, Illinois. Ill. State Mus. Sci. Papers, 3(1): 1-20.

1964. Studies on Carboniferous Insects of Commentry, France. Part 6. The genus Dictyoptilus (Palaeodictyoptera). Psyche, 71(2): 104-116.

1964. Studies on North American Carboniferous Insects. 3. A Spilapterid from the Vicinity of Mazon Creek, Illinois (Palaeodictyoptera). Psyche, 71(3): 117-124.

1965. Studies on North American Carboniferous Insects. 4. The Genera Metropator, Eubleptus, Hapaloptera and Hadentomum. Psyche, $72(2): 175-190$.

1967. Studies on North American Carboniferous Insects. 5. Palaeodictyoptera and Megasecoptera from Illinois and Tennessee with Discussion on the Order Sypharopteriodea. Psyche, 73 (1) : 58-84.

Carpenter, F. M. and E. S. Richardson, Jr.

1969. Megasecopterous Nymphs in Pennsylvanian Concretions from Illinois. Psyche, 75 (4) : 295-309.

Crampton, G. C.

1919. Notes of the Ancestry of the Coleoptera. Pomona Coll. Journ. Ent. Zool., $11(3)$ : 49-54.

Demoulin, G.

1958. Nouvelles observations sur l'aile de Lithoptilus boulei (Meunier) (Insecte Paléodictyoptère). Bull. Inst. Roy. Sci. Nat. Belg., $34(39): 1-5$.

1958. Nouvelles recherches sur Patteiskya bouckaerti Laurentiaux (Insecte Paléodictyoptère). Bull. Soc. Roy. Ent. Belg., 94(11-12): 357-365.

1960. Quelques remarques sur un insecte fossile abracadabrant: Lycocercus goldenbergi (Brongniart, 1885). Bull. Inst. Roy. Sci. Nat. Belg., $36: 1-4$.

DoHrn, A.

1868. Eugereon Boeckingi, eine neue Insektenform aus dem Todtliegenden. Palaeontographica, 13 : 333-340.

Forbes, W. T. M.

1943. The Origin of Wings and Venational Types in Insects. Amer. Midland Naturalist, 29(2): 381-405.

GoLDENBERG, F.

1854. Die fossilen Insecten der Kohlenformation von Saarbrücken. Palaeontographica, 4 : 17-40.

GUThORL, P.

1930. Neue Insektenfunde aus dem Saarcarbon. Neues Jahrb. f. Min., Geol. u. Paleont., Abt. B, 64(1) : 147-164.

1931. Cleffia sarana n.g.n.sp., eine neue Insektenform aus dem Saarcarbon. Centralbl. Min., etc., 1931, B(2): 91-94. 
1934. Die Arthropoden aus dem Carbon und Perm des Saar-NahePfalz-Gebietes. Abh. Preuss. Geol. Landesanst., NF, 164: 1-219.

1940. Zur Arthropoden-Fauna des Karbons und Perms. 11. Neue Insektenfunde (Palaeodictyoptera) aus Schacht 5 der Grube Frankenholz-Saar. Senckenbergiana 22(1/2): 35-73.

Handlirsch, A.

1904. Les insectes houillers de la Belgique. Mém. Mus. Roy. Hist. Nat. Belg., 3 : 1-20.

1906. Revision of American Paleozoic insects. Proc. U. S. Nat. Mus., 29: $661-820$.

1906. Die fossilen Insekten und die Phylogenie der rezenten Formen. Leipzig. 430 pp.

1910. Ueber fossile Insekten. I. Congr. Intern. d'Ent., Bruxelles, 2e partie, pp. 177-184.

1911. New Palaeozoic Insects from the Vicinity of Mazon Creek, Illinois. Amer. J. Sci., 31: 297-326; 353-377.

1919. Revision der palaeozoischen Insekten. Denkschr. Akad. Wiss. Wien. Math. Naturw. Kl., 96: 82 pp.

1921. Palaeontologie. In Schröders Handbuch der Entomologie, 3: 306 pp.

1922. Fossilium catalogus I: Animalia. Insecta palaeozoica. Berlin. $230 \mathrm{pp}$.

1937-39. Neue Untersuchungen über die fossilen Insekten mit Ergänzungen und Nachträgen sowie Ausblicken auf phylogenetische, palaeogeographische und allgemeine biologische Probleme. I. Ann. naturh. Mus. Wien, 48: 1-140; 49: 1-240.

HAUPT, H.

1949. Rekonstruktionen permokarbonischer Insekten. Beitr. taxon. Zool., 1: 23-43.

Kukalová, J.

1958. On Czechoslovakian Spilapteridae Handlirsch (Insecta-Palaeodictyoptera). Acta Univ. Carolinae, Geol., 3 : 231-240.

1959. Breyeria barborae n. sp. (Insecta, Palaeodictyoptera) of Upper Silesian Coal Basin (Westphalian). Vestník UUG, 3.4: 310-313.

1960. New Palaeodictyoptera of the Carboniferous and Permian of Czechoslovakia. Sbornik UUG, 25: 239-251.

1964. Review of the Calvertiellidae, with Description of a New Genus from Permian Strata of Moravia (Palaeodictyoptera). Psyche, $71(4): 153-168$.

1969. Permian Mayfly Nymphs. Psyche, 75(4): 310-327.

LAMEERE, A.

1917. Revision sommaire des insectes fossiles du Stéphanien de Commentry. Bull. Mus. Paris, 23 141-200.

1917. Sur les insectes houillers de Commentry. Bull. Soc. Zool. Fr., 42: 27-37.

1917. Palaeodictyoptères et subulicornes. Bull. Soc. Ent. Fr., 1917: 101-104.

1917. Étude sur l'Évolution des Éphémères. Bull. Soc. Zool. Fr., 42 : 41-81. 
1922. Sur la nervation alaire des Insectes. Bull. Classe Sci. Belgique 1922 (4) : 138-149.

1935. Précis de zoologie. Univ. Bruxelles, 4: 174-214.

LaUrentiaux, D.

1949. Description de trois nouveaux paléodictyoptères du terrain houiller du Nord de la France. Ann. Soc. Géol. Nord., 59: 206-223.

1950. Les insectes des bassins houillers du Gard et de la Loire. Ann. Paléont., 36: 63-84.

1952. Découverte d'un rostre chez Stenodictya lobata Brgt. (Paléodictyoptère sténodictyide) et le probleme des Protohémiptères. Bull. Soc. Géol. France, sér. 6, 2: 233-247

1953. Classe des Insectes. In Traité de Paléontologie, Piveteau, Paris. pp. 397-527.

1958. Patteiskya bouckaerti, nov. gen. et sp., Insekt aus dem Namur des Ruhrkarbons. N. Jahrb. Geol. U. Paleont., 7: 302-306.

Laurentiaux-Vieira, F., and D. Laurentiaux

1951. Observations sur les Paléodictyoptères Breyeriidae. Bull. Soc. Géol. Fr., (6) 1: 585-596.

1963. Nouvelle récolte d'un Breyeriide (Insecte paléodictyoptère) dans le Westphalien du Nord de la France. Ann. Soc. Géol. Nord, 82: 173-178.

1964. Diagramme ptéronologique du genre westphalien Breyeria De Borre (Insectes Paléodictyoptères). C. R. Acad. Sci. Paris, $258(9): 1282-1284$.

Martynov, A. V.

1931. New Permian Palaeoptera with a Discussion of some Problems of Their Evolution. Trav. Inst. Paleozool. Acad. Sci., 1: 1-44.

1931. Palaeozoic Insects from the Kuznetsk Basin. Bull. Geol. Prosp. Serv. USSR, $49(10): 73-100$.

1938. Études sur l'histoire géologique et de phylogénie des ordres des insectes (Pterygota). 1e partie. Palaeoptera et Neoptera-Polyneoptera. Trav. Inst. Paléont. Acad. Sci. URSS, 7(4): 1-150.

Metcalf, $Z$. P.

1952. New Names in the Homoptera. J. Wash. Acad. Sci., 42: 226-231.

Meunier, F.

1908. Un Platyptéride et un Sténodictyoptéride du Stéphanien de Commentry. Ann. Soc. Sci. Brux., 32 (2) : 153-154.

1908. Nouveaux Paléodictyoptères du Stéphanien de Commentry. Bull. Mus. Hist. Nat., 14: 34-36.

1909. Nouveaux insectes de Stéphanien de Commentry. Bull. Mus. Hist. Nat. Paris, 15: 37-40.

1909. Insectes de Stéphanien de Commentry. Bull. Mus. Hist. Nat. Paris, 15: 40-49.

1909. Nouvelles recherches sur les insectes du terrain houiller de Commentry. Ann. Paleont., 4: 125-152.

1909. Nouveaux Paléodictyoptères et Protorthoptères du Stéphanien de Commentry. Ann. Soc. Sci., 33: 139-140.

1910. Nouveau Paléodictyoptères du houiller de Commentry. Bull. Mus. Hist. Nat., 16: 233-237. 
1911. Nouveaux insectes du houiller de Commentry. Bull. Mus. Hist. Nat., 17 : 117-128.

1912. Nouvelles recherches sur quelques insectes du terrain houiller de Commentry. Deuxième part. Ann. Paléont. Paris. 7: 1-19.

Pruvost, P.

1919. Introduction a l'étude du terrain houiller du Nord et du Pas-deCalais: La Faune continentale du terrain houiller du Nord de la France. Paris. 584 pp. [Thesis].

Richardson, E. S., JR.

1956. Pennsylvanian Invertebrates of the Mazon Creek Area, Illinois. Fieldiana: Geology, 12(2): 15-56.

Rohdendorf, B. B. and E. E. Becker-Migdisova, O. M. Martynova,

A. G. Sharov

1961. Paleozoic Insects of the Kuznetsk Basin. Trudy Paleont. Inst., $85: 705 \mathrm{pp}$.

ROHDENDORF, B. B., ET AL.

1962. Principles of Paleontology. Akad. Nauk SSSR, Moscow, 535 pp. ScUDDER, S. H.

1885. Systematische Ubersicht der fossilen Myriopoden, Arachnoideen und Insekten. In Zittel, Handb. d. Palaeont., I. Abt., Palaeozool., 2: 721-831.

Sharov, A. G.

1966. Basic Arthropodan Stock with special reference to insects. Int. STRAND, E. Ser. Monogr. Pure Appl. Biol., Zool., 30: 272 pp.

1929. Zoological and palaeontological nomenclatorial notes. Acta Univ. Latviensis, 20: 1-29.

Teixeira, C.

1941. Nouveaux insectes du Stéphanien portugais. Bol. Soc. Geol. Portugal, 1(1): 1-21.

Tillyard, R. J.

1924. Kansas Permian Insects. Part I. The Geologic Occurrence and the Environment of the Insects With Description of a New Palaeodictyopterid. Amer. Journ. Sci., (5) 7: 203-208.

Amer. Journ. Sci., 9: 328-335.

1925. Kansas Permian Insects. Part 4. The Order Palaeodictyoptera. Amer. Journ. Sci., 9: 328-335.

WOODWARD, $\mathrm{H}$.

1906. A fossil Insect from the Coal Measures of Loughton, N. Staffordsh. Geol. Mag. (5) 3: 25-29.

ZALESSKY, G.

1946. Sur un nouveau representant de l'ordre des palaeodictyoptères du Paleozoique superieur de bassin de Kousnetsk. Moscow. Ob. Isp. Prirody, Biol. (N.S.), 51: 58-62. 

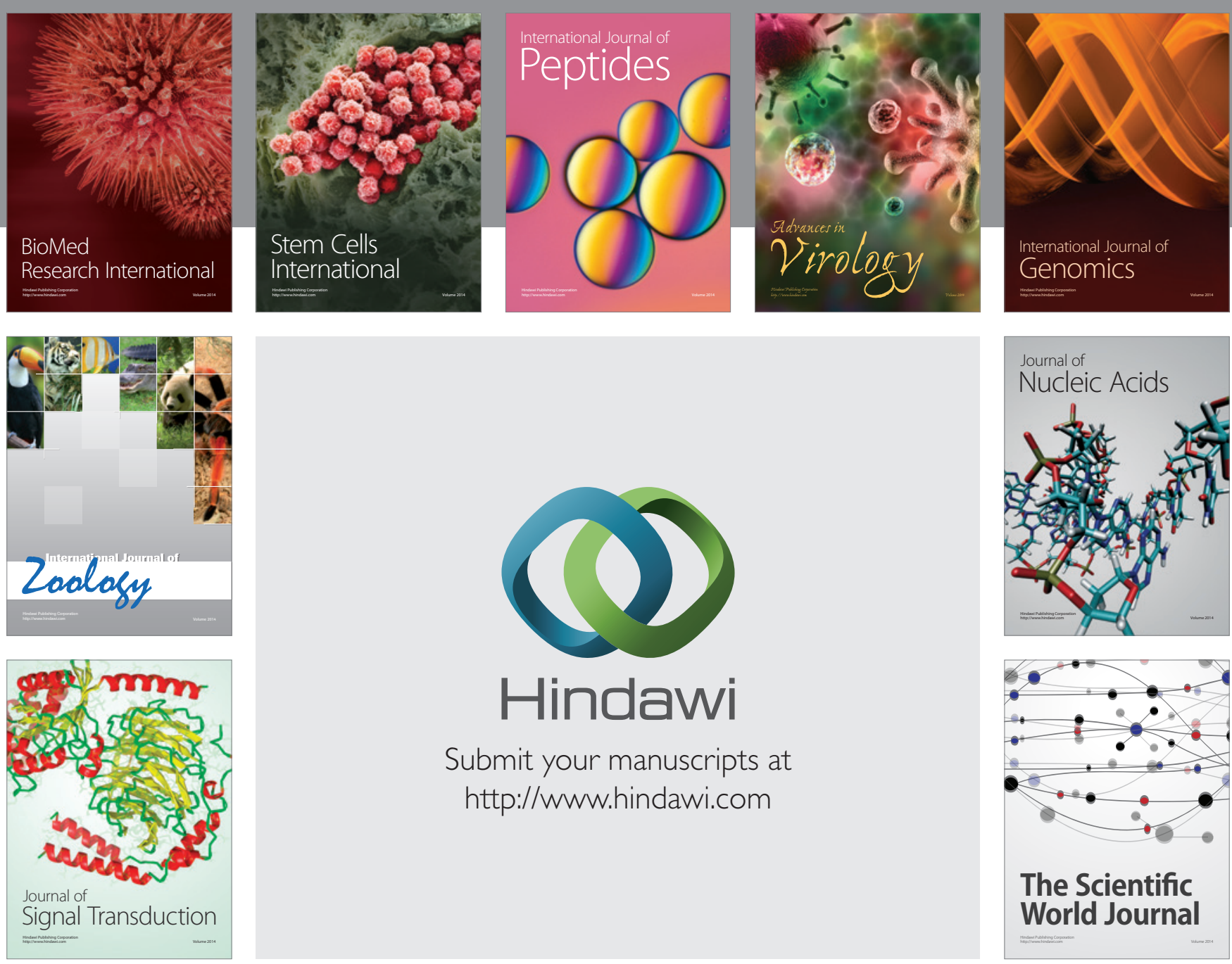

Submit your manuscripts at

http://www.hindawi.com
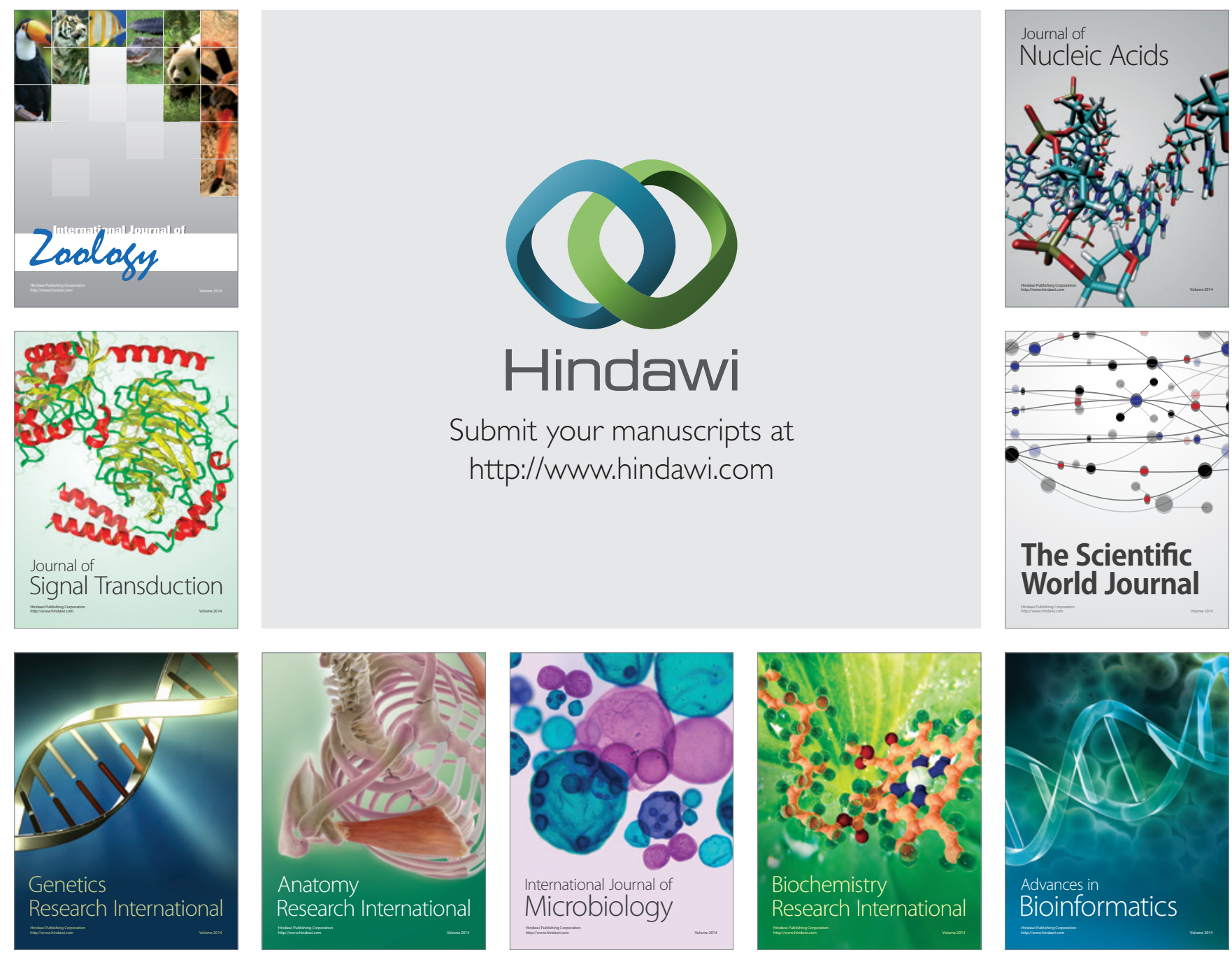

The Scientific World Journal
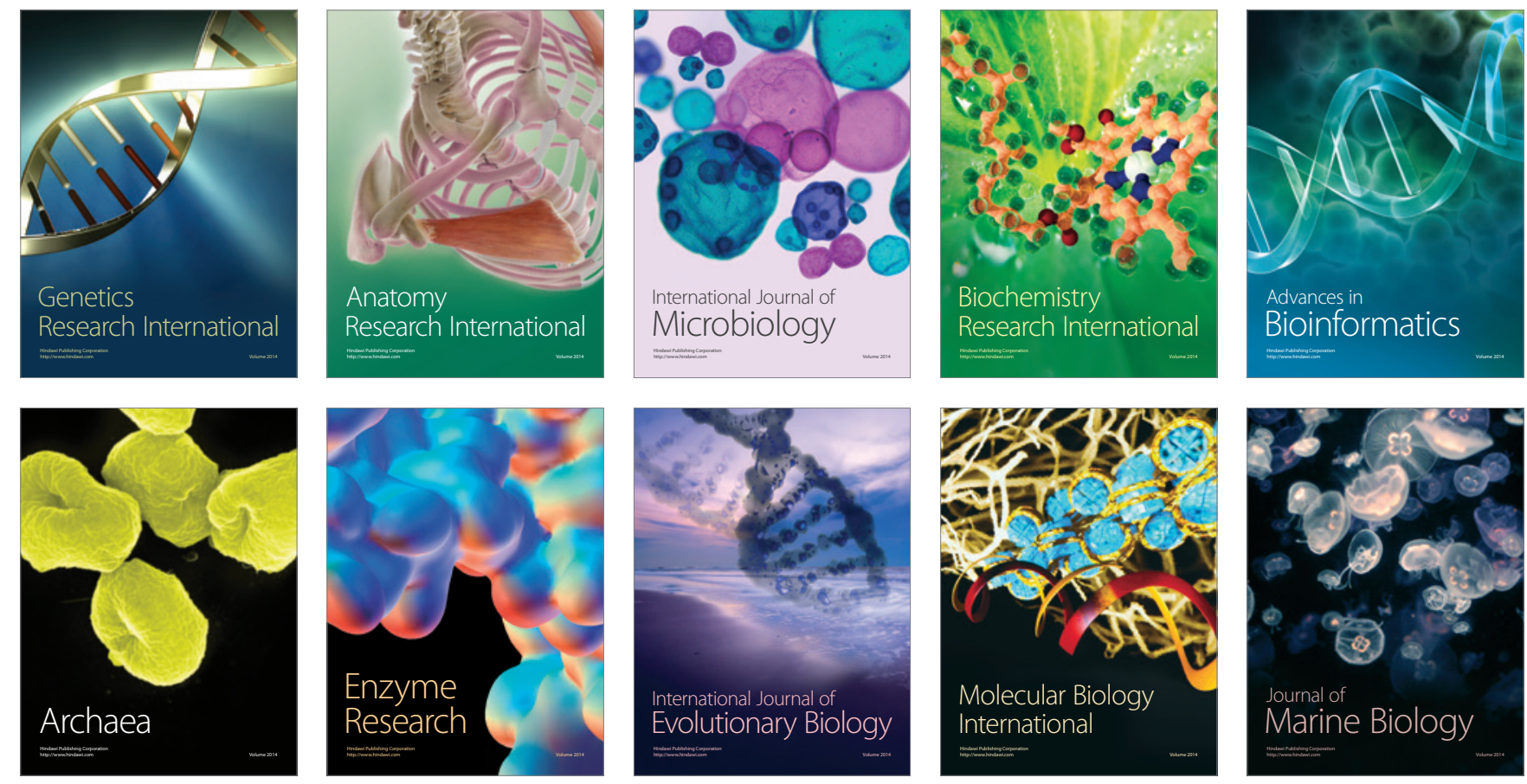